\title{
Central Nervous System Tissue Regeneration after Intracerebral Hemorrhage: The Next Frontier
}

\author{
Ruiyi Zhang ${ }^{1,2}$, Mengzhou Xue ${ }^{2, *}$ and Voon Wee Yong ${ }^{1, *(\mathbb{D}}$ \\ 1 The Hotchkiss Brain Institute and the Department of Clinical Neurosciences, University of Calgary, \\ Calgary, AB T3A 4X9, Canada; ruiyi.zhang@ucalgary.ca \\ 2 The Second Affiliated Hospital of Zhengzhou University, Zhengzhou 450014, China \\ * Correspondence: xuemengzhou@zzu.edu.cn (M.X.); vyong@ucalgary.ca (V.W.Y.)
}

check for updates

Citation: Zhang, R.; Xue, M.; Yong, V.W. Central Nervous System Tissue Regeneration after Intracerebral Hemorrhage: The Next Frontier. Cells 2021, 10, 2513. https://doi.org/ 10.3390/cells10102513

Academic Editors: Giovanni Amabile and Cord Brakebusch

Received: 1 September 2021

Accepted: 17 September 2021

Published: 23 September 2021

Publisher's Note: MDPI stays neutral with regard to jurisdictional claims in published maps and institutional affiliations.

Copyright: (c) 2021 by the authors. Licensee MDPI, Basel, Switzerland. This article is an open access article distributed under the terms and conditions of the Creative Commons Attribution (CC BY) license (https:// creativecommons.org/licenses/by/ $4.0 /)$.

\begin{abstract}
Despite marked advances in surgical techniques and understanding of secondary brain injury mechanisms, the prognosis of intracerebral hemorrhage $(\mathrm{ICH})$ remains devastating. Harnessing and promoting the regenerative potential of the central nervous system may improve the outcomes of patients with hemorrhagic stroke, but approaches are still in their infancy. In this review, we discuss the regenerative phenomena occurring in animal models and human ICH, provide results related to cellular and molecular mechanisms of the repair process including by microglia, and review potential methods to promote tissue regeneration in ICH. We aim to stimulate research involving tissue restoration after $\mathrm{ICH}$.
\end{abstract}

Keywords: intracerebral hemorrhage; tissue regeneration; neurogenesis; remyelination; angiogenesis; neuroinflammation; drug therapy; stem cells; rehabilitation; biomaterial

\section{Introduction}

Intracerebral hemorrhage ( $\mathrm{ICH}$ ) accounts for 12-20\% of all types of stroke with over 2 million individuals worldwide being afflicted annually [1]. ICH has catastrophic outcomes with up to $50 \%$ mortality and $70 \%$ disability among the survivors a year after onset [2]. A study of global disease burden shows that $\mathrm{ICH}$ cases have increased by $47 \%$ over the past 20 years, occurring mostly in low-income and middle-income countries [3]. This life-threatening stroke subtype can be induced by a variety of causes, including hypertension, cerebral amyloid angiopathy, trauma, vascular malformations, tumors, premature birth, and with certain drugs [4]. Even though the development of minimally invasive surgery targeting the primary injury has alleviated neurological deficits or reduced mortality [5-7], the prognosis of ICH remains unsatisfactory. Accordingly, scholars have turned their focus on mitigating ICH-induced inflammation and consequent secondary brain injury with significant promise preclinically and some results being clinically translated [8].

The restorative capability of the central nervous system (CNS) after ICH has received little attention, even though it is clear that the brain has capacity for repair after injury [9-11]. The dynamic changes of myelin (de- and remyelination) can be found in brains of patients with multiple sclerosis and Alzheimer's disease [12,13]; a novel transgenic reporter mouse line shows proof of myelin renewal in normal homeostasis [14]. Enhanced neural regenerative processes including neurogenesis, angiogenesis, oligodendrogenesis, and axonal regeneration have been observed in divergent CNS pathologies [15-17]. Moreover, it is commonly observed that patients with ICH gradually recover some neurofunctional deficits several months after the stroke [18]. Such a phenomenon suggests that reorganization or regeneration of neural elements occurs after $\mathrm{ICH}$, giving optimism that tissue recovery in ICH may be promoted to improve its prognosis. To achieve this goal, the regenerative events in $\mathrm{ICH}$ at the cellular and molecular level, and the mechanisms thereof, must be better understood. In this review, we have collated available evidence that regenerative processes occur after ICH in animal models, and we describe the sparse 
information currently available for patients with ICH. We describe these changes, evaluate the enabling mechanisms, and discuss potential methods to facilitate $\mathrm{CNS}$ repair in $\mathrm{ICH}$.

\section{Regenerative Processes Occur after ICH in Animal Models}

Evidence from animal models supports the occurrence of brain regenerative processes after ICH and which are detectable by $72 \mathrm{~h}$ in multiple forms [19]. For neurogenesis, enhanced proliferation of neural progenitor cells (NPCs) in the subventricular zone (SVZ) and striatum is observed 14 days after collagenase-induced ICH in the striatum near the internal capsule. Both bromodeoxyuridine (BrdU, an index of cell proliferation) or doublecortin (DCX, a marker of neuroblasts) single-positive cells are dramatically increased in the ipsilateral and contralateral hemisphere of ICH compared to the sham group, with some being double positive $[20,21]$. Another group also demonstrates neurogenesis after collagenase-induced ICH through the robust increase in $\mathrm{Ki}_{6} 7^{+} / \mathrm{DCX}^{+}$and $\mathrm{Ki} 67^{+} /$nestin $^{+}$ cells from $72 \mathrm{~h}$ to 7 days in SVZ [22]; Ki67 is a marker of cycling cells while nestin is an early marker of neuronal lineage cells. However, most of these proliferated cells could not survive more than 3 weeks due to extensive apoptosis [22].

Besides proliferation, the migration of DCX+cells from SVZ to the perihematomal area has been observed by immunohistochemistry on days 14 and 28 after ICH induction [20]. Moreover, neuronal NeuN and BrdU double-positive cells are observed to be increased after 30 days in the hippocampal dentate gyrus of a subarachnoid hemorrhage (SAH) mouse model, which may be the result of proliferation, migration, and differentiation of NPCs [23].

Remyelination may be crucial for axonal maintenance and functional recovery due to the anatomical affinity of ICH, and deserves more attention. Hypertension-related ICH is the most common subtype of hemorrhagic stroke [24-26], often at the lenticulostriate artery and thalamus because of the rectangular structure [27]. The hematoma formed and enlarged here can compress adjacent white matter fibers, destroy myelin and axons, and leads to typical symptoms on the contralateral side. Prominent amounts of immunoreactivity for degraded myelin basic protein from degenerating myelin could be seen 1 day after collagenase injection, indicating acute and severe demyelination [28]. White matter tract injury shown on diffusion tensor imaging of ICH patients also supports the existence of demyelination [29]. Although much of our knowledge of white matter remyelination comes from the prototypical demyelinating disease multiple sclerosis, which shows that remyelination can be robust after lesion formation [30], it is plausible that there are remyelinating processes after ICH due to the capacity of oligodendrocyte lineage cells to repopulate a lesion. Indeed, in the collagenase-induced ICH model, both mature oligodendrocytes and oligodendrocyte precursor cells (OPCs) are markedly increased as determined by elevated $\mathrm{CC}^{+} \mathrm{Olig} 2^{+}, \mathrm{NG}^{+} \mathrm{Olig} 2^{+}$and $\mathrm{Ki} 67^{+} \mathrm{Olig} 2^{+}$cells, especially in the first 7 days post-ICH [31]; Olig2 is a transcription factor that defines cells of the oligodendrocyte lineage, while CC1 and NG2 are markers of mature oligodendrocytes and OPCs, respectively. These results demonstrate the existence of oligodendrogenesis after experimental ICH. Moreover, the proliferated Olig2 ${ }^{+}$cells are preferentially gathered inside the white matter bundles [31]. However, this research did not reveal whether these newly formed oligodendrocytes complete the remyelination process, requiring further investigation.

The basic primary pathology of ICH is the rupture of arterial walls and the formation of a hematoma, causing severe disruption of perfusion, circulation, and blood-brain barrier (BBB) permeability [32,33]. Because the brain is highly dependent on a blood supply for glucose and oxygen, reformation of the microvasculature is vital for post-ICH brain repair. Spontaneous angiogenesis can be observed around the hematoma in rats after collagenase-induced ICH [34]. The von Willebrand factor positive endothelial cells are noted to proliferate from 4 days and peak between 7 and 14 days after $\mathrm{ICH}$ as determined by increased $\mathrm{BrdU}^{+}$counting. The level of vascular endothelial growth factor (VEGF) is also upregulated alongside its receptors including Flt-1 and Flk-1 [34]. 
In summary, the CNS has some degree of regenerative ability after ICH in animal models (Figure 1). The literature is still sparse, and it remains to be documented that the regenerative events are productive and lead to functional recovery. Nonetheless, the observation of tissue regeneration in $\mathrm{ICH}$ is promising and suggest that the process could likely be promoted if there is more knowledge of these reparative processes and of their mechanisms.

SVZ

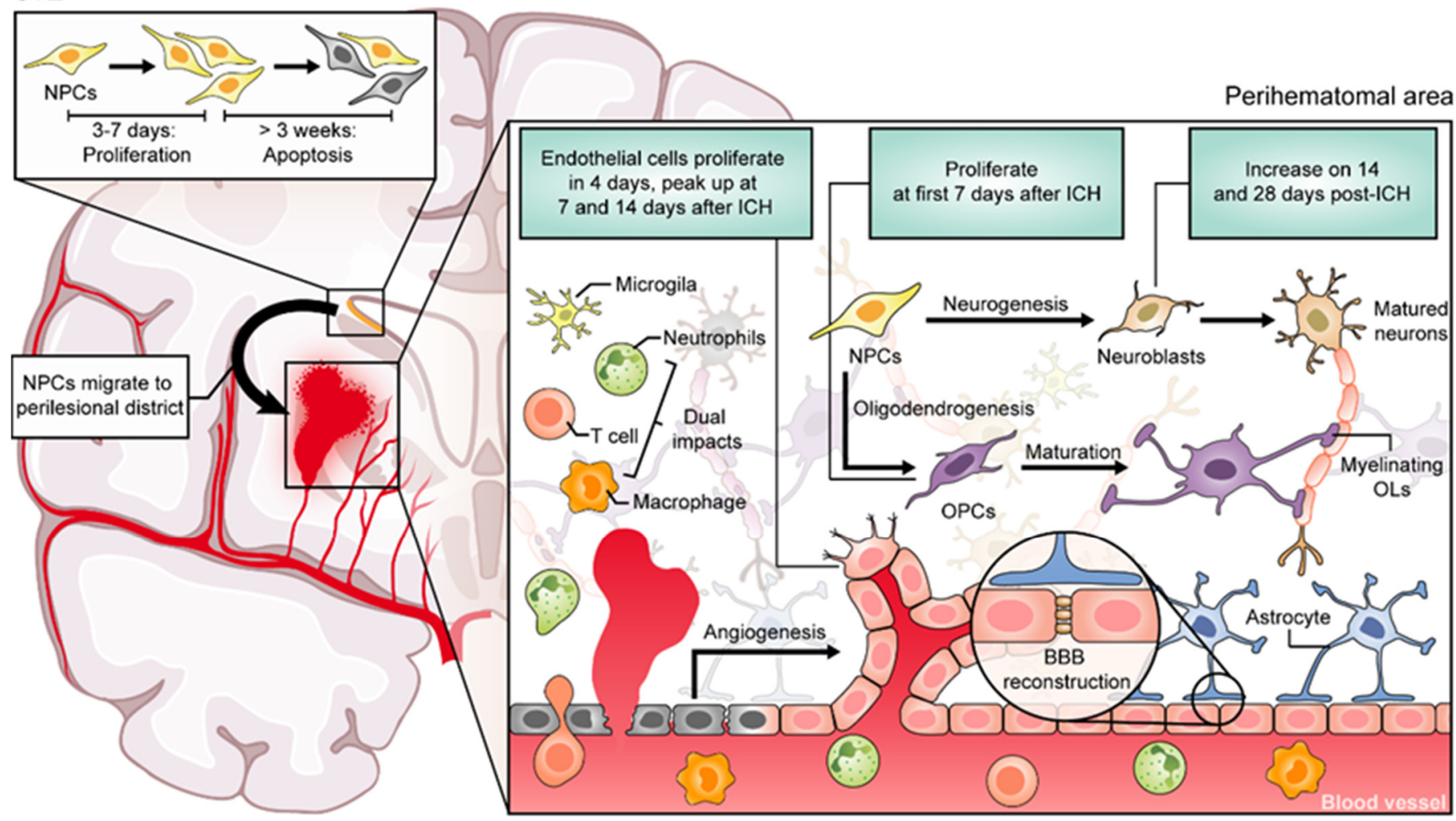

Figure 1. Signals from tissue damage and inflammatory cells may trigger the process of repair. Neural precursor cells (NPCs) proliferate from SVZ and migrate to the perihematomal area and differentiate into neurons and glia, contributing to brain restoration. However, most of these NPCs could not survive more than 3 weeks due to extensive apoptosis. Moreover, the proliferated Olig2 ${ }^{+}$cells were preferentially gathered inside the white matter bundles, although there are no data on whether these newly formed oligodendrocytes contribute to subsequent remyelination. Inflammatory products from resident and infiltrated immune cells promote or hinder tissue recovery according to their phenotypes.

\section{Evidence of CNS Regeneration in Patients with ICH}

Brain samples from ICH patients are precious specimens to evaluate regenerative process after the insult. In the perihematomal region, markers of neuronal lineage cells indicating neurogenesis can be found, including doublecortin, the stem-like marker musashi1, and TUJ- 1 and TUC-4 that indicate growth cone signaling; some of the NPCs are also Ki67 positive indicating proliferation [35]. As these samples were collected during 1-3 days post-ICH from hematoma removal surgery, the results suggest that neurogenesis occurs very soon after ictal onset.

Interestingly, postmortem research indicates that NPCs detected by $\mathrm{p}$-Histone $\mathrm{H} 3_{\mathrm{Ser}-10}$ positive staining in the dentate gyrus in ICH patients are significantly higher than those with ischemic stroke [36], for reasons that are not clarified. In samples from subarachnoid hemorrhage patients, neurogenesis and NPC proliferation are demonstrated by Musashi $2^{+}$, $\mathrm{Ki} 67^{+}$and double-positive cells in the frontal lobe, while none of these labeled cells are seen in the control group [37]. 
Overall, signs of regenerative processes are seen after ICH in patients, but the studies are rare. Many more datasets must be forthcoming.

\section{Neuroinflammation may Mediate Regenerative Processes after ICH: Guides from Experimental ICH}

While the involvement of neuroinflammation in mediating secondary injury after $\mathrm{ICH}$ is well documented and reviewed [8,38,39], components of the inflammatory response also appear to be crucial to the reparative response after ICH (Figure 1). This should not be surprising since a fundamental role of an immune response is to help with healing after an insult. Here, we summarize immune cell subsets and their involvement in regenerative processes after ICH in preclinical models.

\subsection{Microglia}

Microglia comprise $5-10 \%$ of the total cell population in the normal brain. They are an early responder to injury in the CNS $[38,40]$. In a postmortem study, activated microglia are evident from day 1 after onset and dramatically increased to ninefold on day 12 post-ICH compared to controls [41].

In preclinical research, activated microglia are observed within the perihematomal area by $1 \mathrm{~h}$ of collagenase-induced ICH and $4 \mathrm{~h}$ post-autologous blood injection of ICH $[42,43]$. As microglia and infiltrated blood monocyte-derived macrophages display many similar markers and morphology, we refer to them as microglia/macrophages (M/M) when they have not been differentiated from one another in quoted studies. Accumulation of M/M is observed early after ICH [38] where their manifestation of pro-inflammatory ("M1"like) phenotype leads to the release of a series of inflammatory cytokines, chemokines, matrix metalloproteinases (MMPs), free radicals, and other molecules that exacerbate neuroinflammation and secondary brain injury [44-46]. Depletion of microglia by colonystimulating factor receptor 1 (CSFR1) inhibitor PLX3397 results in a reduction in lesion volume in the early stage ( 1 or 3 days post-surgery) of both collagenase and autologous blood-induced ICH [47]. However, the M/M cluster gradually transforms to a regulatory ("M2"-like) phenotype that increases from about 3 days post-ICH, peaks and dominates at around 14 days; these clusters are thought to promote tissue repair function including phagocytosis, remyelination, neurogenesis, and angiogenesis in CNS pathologies $[39,48,49]$. The intracerebral injection of interleukin-4 (IL-4) promotes the conversion of $\mathrm{M} / \mathrm{M}$ to a regulatory phenotype displaying arginase 1 and improves functional recovery in ICH model [50]. The administration of another regulatory cytokine IL-10 intraventricularly increases the number of "M2"-like $\mathrm{M} / \mathrm{M}$ and aids hematoma clearance by enhanced phagocytosis after injury [51].

The transcription factor nuclear factor-erythroid 2 p45-related factor 2 (Nrf2), a master regulator of antioxidative defense, may play a critical role in the phagocytosis ability of microglia. Nrf2 knockout mice have impaired hematoma clearance while administration of Nrf2 activator enhances such functions after ICH [52]. The activation of cannabinoid receptor- 2 boosts "M2"-like microglia polarization in the acute stage after experimental $\mathrm{ICH}$, which alleviates brain injury and neurological deficits [53]. Infiltrating macrophages contribute to hematoma clearance and tissue repair, and depleting peripheral monocytes with clodronate liposomes results in a larger lesion and neurological impairment [54]. In research about applying hirudin to improve long-term outcome after experimental ICH, M/M were found shifted to regulatory phenotype, and depleting M/M by PLX 3397 weakened the protective effect [55]. Recent research demonstrated that CD47 blocking antibody facilitated hematoma and iron clearance by microglia/macrophage while clodronate liposome-induced M/M elimination caused exacerbated brain edema, neuronal death, and functional deficits [56].

There is substantial literature describing the roles of $\mathrm{M} / \mathrm{M}$ in mediating or promoting the extent of injury after ICH. We refer the reader to these reviews $[38,57,58]$. In contrast, the involvement of $\mathrm{M} / \mathrm{M}$ in facilitating repair processes in ICH appears limited by the few citations noted above. Nevertheless, it is not clear from present data whether regulatory 
$\mathrm{M} / \mathrm{M}$ directly promote $\mathrm{CNS}$ regeneration, or just neuroprotection after $\mathrm{ICH}$. Work in this field is in urgent need and has substantial promises.

\subsection{Astrocytes}

Astrocytes also display controversial functions in brain repair of ICH [59]. On the one side, reactive astrocytes generated after injury can evolve to excessive scar formation and inhibit repair processes [60]. They may increase lesion volume by generating pro-inflammatory molecules $[60,61]$ and they produce inhibitory molecules including chondroitin sulfate proteoglycans, ephrins, and semaphorins that interfere with remyelination and functional recovery after brain injury [60]. Conversely, astrocytes are engaged with the repair of white matter tracts through promoting axonal regeneration and remyelination in stroke mice [62]. The neurotrophic factors secreted by reactive astrocytes facilitate the survival and migration of OPCs and NPCs that assist with remyelination and neurogenesis [62]. Inhibition of astrocyte reactivity by fluorocitrate weakens neurovascular reconstruction and worsens functional recovery in a mouse model of ischemic stroke [63]. Some subtypes of astrocyte are also reported to facilitate BBB recovery and white matter repair in the animal models of MS, spinal cord injury, neurodegenerative diseases, and tissue culture [64-66], but the data related to astrocyte in the repair phase of experimental $\mathrm{ICH}$ remain few and further investigation is essential.

\subsection{Leukocytes}

Infiltrated neutrophils could be observed within several hours after ICH onset and they accumulate over the next few days in the perihematomal area [41,67]; they are prominent sources of potentially detrimental molecules such as MMP-9, ROS, and TNF- $\alpha$ [8]. In support, higher blood levels of neutrophils after ICH correlate with perihematomal edema and poor functional recovery in patients $[68,69]$.

However, on the bench side, a recent study reports a protective role of infiltrated neutrophils by secretion of lactoferrin, which aids the clearance of ferric iron, reduces injury and promotes functional recovery; this beneficial polarization of neutrophils is triggered by IL-27 from activated microglia after ICH induction in rats [70].

T lymphocytes can be found within the perihematomal region 1-3 days after symptom attack with moderate accumulation in ICH patients [41,71]. A meta-analysis showed that a low neutrophil-lymphocyte ratio predicted a better outcome including less probability of major disability and short-term mortality [72], which might suggest that the infiltration of $\mathrm{T}$ cells was generally beneficial for post-hemorrhagic recovery. The protective effect may come from regulatory $\mathrm{T}$ cells (Tregs) that promote $\mathrm{M} / \mathrm{M}$ polarization to a regulatory phenotype in ICH models while deletion of Tregs exacerbates the injury [73,74].

It is plausible that ICH-induced inflammatory responses can mediate both salutary and adverse effects on brain regeneration and functional recovery depending on different stages and cellular phenotypes. Interventions aimed at harnessing the benefits of neuroinflammation are valuable for further investigation, and they have a highly translational potential for promoting tissue repair and improving prognosis for ICH patients.

\section{Molecular Mechanisms Affecting Post-ICH Tissue Regeneration}

Many of the molecules implicated in exacerbating tissue injury post-ICH appear also to be important in the subsequent repair process (Figure 2). 


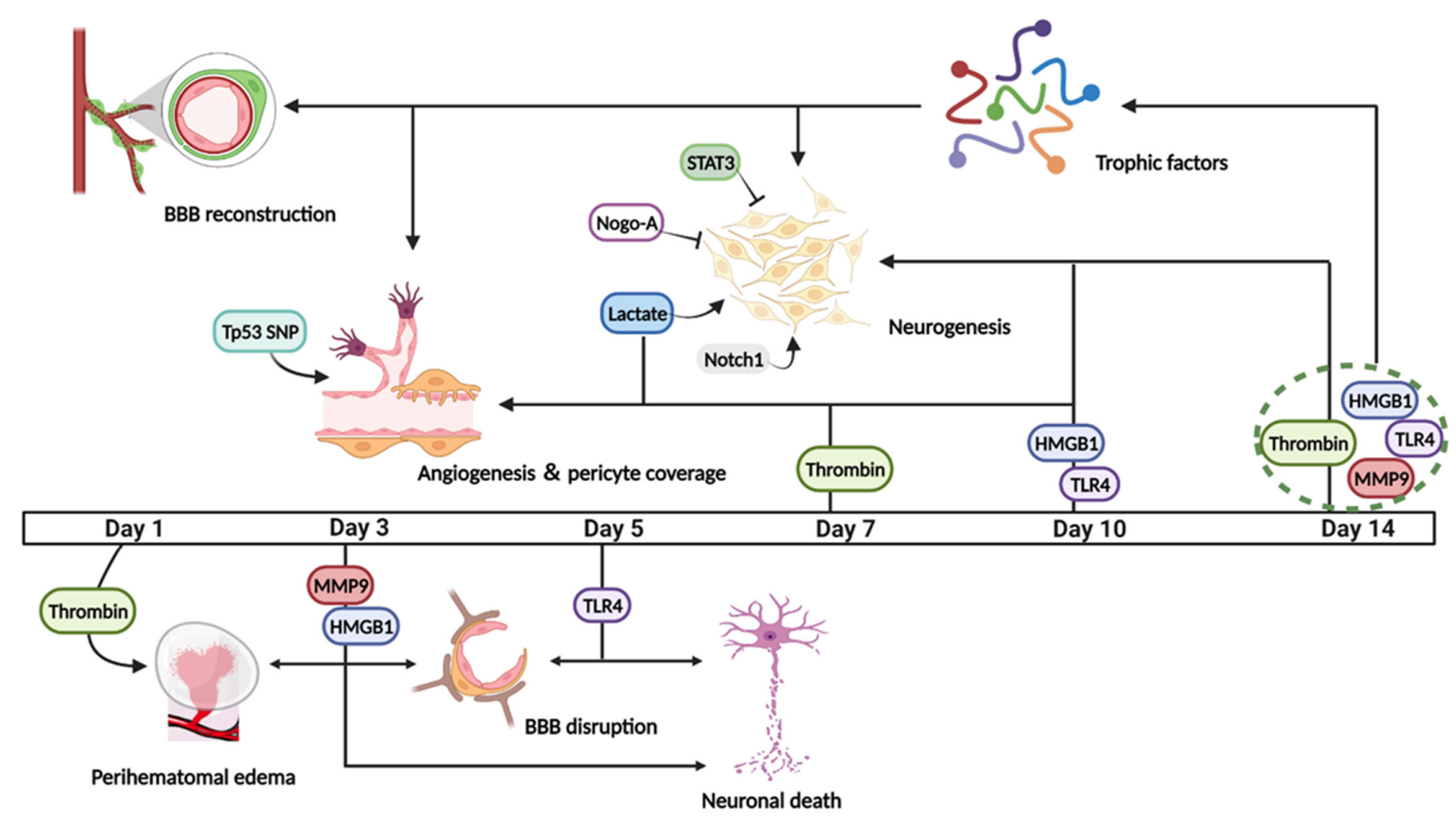

Figure 2. Some molecules including thrombin, MMP-9, HMGB1, TLR4, show divergent effects on post-ICH repair. They tend towards causing pathological changes such as brain edema, BBB disruption, neuronal degeneration, or death in the early phase after $\mathrm{ICH}$, but convert to beneficial regenerative processes by increasing DCX+ cells, promoting endothelial proliferation, pericyte coverage, and stimulating trophic factors at the later stage after ICH. Moreover, the expression of STAT3 and Nogo-A after experimental ICH is observed to inhibit neurogenesis, while Notch1 and the generation of lactate can promote this process.

As a nexus of coagulating response, thrombin is activated acutely in ICH lesions and it is implicated in BBB disruption, brain edema, and neuronal death in the early phase of ICH $[75,76]$. However, thrombin shows the ability to elicit neurogenesis by increasing $\mathrm{DCX}^{+}$cells in experimental ICH, and this beneficial effect is neutralized by thrombin inhibition [77]. Post-ICH angiogenesis could also be triggered by thrombin in autologous blood model; proliferation of endothelial cells is dramatically upregulated following thrombin injection as well as levels of VEGF, hypoxia-inducible factor- $1 \alpha$ (HIF- $1 \alpha)$, and angiopoietin-1 (Ang-1) and Ang-2, which are all crucial factors for angiogenesis [78]. These thrombininduced regenerative processes might be attributed to the activation of protease-activated receptor-1 (PAR-1) [79-81]. Moreover, pericyte (an essential component of a neurovascular unit) coverage is significantly reduced by thrombin inhibition in $\mathrm{ICH}$ rats, which indicates the support of BBB reconstruction by thrombin [82]. In addition, thrombin facilitates the synthesis and secretion of nerve growth factor in glia which improves neurite outgrowth after brain injury [83].

The role of MMP-9 has been widely explored as an injurious factor in ICH. It can degrade the extracellular matrix [84-86] and contributes to BBB disruption; it enhances inflammation, perihematomal edema, and worse lesional outcome after ICH [87-92], especially in the acute phase. However, more recent data show that increased MMP-9 may promote neurogenesis and angiogenesis in an ICH model, whereas intraventricular administration of MMP-9 siRNA on day 7 and 10 reduces the level of VEGF and NGF as well as DCX and BrdU positive cell counts at day 10 and 14 post-injury [93]. It is proposed that MMP-9 displays dual effects in ICH, and the key to utilizing its advantage might be its administration at particular points after stroke [94].

High mobility group box1 (HMGB1) is a highly conserved DNA-binding protein related to inflammatory responses by triggering various pattern recognition receptors 
(PRRs) after ICH and has both beneficial and harmful effects [95-99]. Studies focused on regeneration found that HMGB1 level is positively correlated with VEGF, BDNF, and NGF concentration after collagenase induced ICH; inhibition of HMGB1 reduces the number of proliferating cells and neural precursor cells as well as the level of trophic factors, supporting the promotive function of HMGB1 on neurogenesis and angiogenesis $[100,101]$. Further investigation reveals that the neurogenic and angiogenic effect may be due to the activation of the receptor for advanced glycation end-products (RAGE), a pattern recognition receptor, by HMGB1 in the later phase after experimental ICH [101,102]. Tolllike receptor 4 (TLR4) is also a member of pattern recognition receptors, expressed on neurons and glia, which acts in diverse roles in CNS injury [103]. In experimental ICH, TLR4 stimulation aggravates DNA damage, neuronal death, and neurological deficits at 1,3 , and 5 days after injury [104]. However at 14 days post-ICH, the TLR4 antagonist TAK-242 lowers NPC counts and content of BDNF and VEGF, suggesting that delayed TLR4 activation may improve brain tissue recovery [105].

Lactate accumulation is observed in patients and in a pig model of ICH [106,107]. This metabolic intermediate of glycolysis was once regarded as a symbol of neuronal dysfunction until lactate was found to assist synaptic activity and be utilized by neurons [108-110]. Inhibition of lactate dehydrogenase markedly reduces the number of newly formed endothelial cells and NPCs, whereas exogenous lactate administration boosts angiogenesis and neurogenesis by increasing NFKB translocation [111].

The Human Tp53 gene regulates the apoptotic activity of tumor suppressor protein P53 in physiological conditions, displaying a single-nucleotide polymorphism (SNP) at codon 72 with an arginine-to-proline amino-acidic substitution [112-115]. Recent data show that patients harboring the proline allele have better functional outcomes with a higher VEGF level and circulating $\mathrm{CD} 34^{+}$endothelial progenitor cells than homozygous arginine patients after ICH [116], which may occur due to better neurovascularization [117]. Humanized proline allele knock-in reduces apoptosis of CD31+ endothelial cells in collagenase-induced ICH mice while promoting angiogenesis and functional recovery compared to the arginine allele carrying group [116].

Several other mediators with limited data are also implicated in repair after ICH. STAT3 regulates many important physiological functions including cellular proliferation, migration, and angiogenic activity [118]. However, STAT3 signaling may interfere with neurogenesis and recovery after experimental ICH and inhibition of the pathway increases proliferating neural progenitor cells around the hematoma [119]. Nogo-A is a myelinrelated protein exerting an inhibitory effect on axonal growth after brain injury [120,121]. ICH-induced activation of Nogo-A and its downstream signaling pathway impair neuronal survival and axonal regeneration in a rat model of collagenase injection [122]. Notch1 signaling is related to neurogenesis in the adult brain, which regulates proliferation and differentiation of neural stem cells [123]. In the autologous blood ICH model of mice, upregulating Notch1 expression increases the number of neural stem cells in the hippocampal dentate gyrus while promoting performance in behavior tests on day 28 after injury [124].

The research about molecular mechanisms related to regeneration after ICH remains sparse. It would be an urgent task to uncover more data and integrate them to acquire a broad interacting molecular network of repair processes after ICH.

\section{Strategies to Promote Neural Regeneration after ICH}

\subsection{Medications}

Many medications or substances have been observed to confer neuroprotection and lead to improve functional recovery or histological outcomes in animal models, and we refer the reader to excellent reviews elsewhere $[8,125,126]$. Here we focus on the drugs that show potential on promoting tissue repair in preclinical research of ICH.

Statins have been widely used to prevent ischemic stroke $[127,128]$, but concerns about increasing the risk of ICH remain $[129,130]$. However, growing evidence suggests that statin use in primary or secondary prevention of ischemic stroke does not elevate 
the risk of acquiring ICH [131-133]. The ongoing SATURN trial may resolve the safety of statins in ICH patients. Interestingly, a pilot study reported lower mortality of $\mathrm{ICH}$ patients in the rosuvastatin treatment group [134]. Additional data from a cohort study lasting 10 years in Denmark report that stroke-free statin users had a 22-35\% lower risk for ICH compared to reference subjects [133]. In preclinical ICH, the results of statin treatment are usually beneficial. In an autologous blood induced model, simvastatin or atorvastatin given to rats daily for 1 week post-injury augments the number of $\mathrm{DCX}^{+}$neural precursor cells and $\mathrm{BrdU}^{+}$proliferating cells along with better neurological functions compared to controls at 28 days; ameliorated tissue loss at this time point is observed by both MRI and histology [135]. In the same model, enhanced neurogenesis and synaptogenesis is reported by an earlier study that shows increased DCX, synaptophysin and TUJ 1 positive cells with treatment of statin [136]. Statin is also documented to stimulate the generation of VEGF, BDNF, and NGF, which may facilitate repair after ICH through neurotrophic ways [137]. Angiogenesis and revascularization can be promoted by statin in rat model, observed in both histology and MRI [138]. In another study, statin was found to stimulate "M2"-like polarization of microglia with enhanced phagocytosis function, which promotes hematoma and iron clearance, leading to better tissue and functional recovery [139]. Moreover, statin may act as a immunomodulator to inhibit excessive inflammatory response in the early phase after experimental ICH to limit secondary brain injury [8].

Minocycline is often tested as a microglia inhibitor to control injurious neuroinflammation soon after experimental ICH where it displays various therapeutic effects [140-142]. The inhibition of proinflammatory microglia phenotype seemingly does not interfere with the regulatory properties of microglia [143]. In autologous blood induced ICH rats, administration of minocycline facilitates an "M2"-like polarization and increases microglia-derived BDNF; enhanced neurogenesis is observed with more DCX and Tuj-1 positive neuron-like cells than in a control group at $24 \mathrm{~h}$ after ICH onset [144]. Another study reported NGF elevation by minocycline after collagenase ICH [145]. However, minocycline injection is documented to inhibit angiogenesis by downregulating the level of VEGF and its receptors after experimental ICH, which may hinder tissue regeneration in the late phase [146]. For now, all completed clinical trials demonstrate safety but not efficacy of minocycline treatment for cerebral hemorrhage [147,148], although the studies are not powered for efficacy. The roles and usage of minocycline in ICH still need more investigation from both clinical and preclinical work.

Four of five sphingosine-1-phosphate receptors (S1PR1, S1PR2, S1PR3, and S1PR5) are found expressed at different levels in divergent neural cells of the CNS. S1PR1 activation is reported to be linked to neuronal growth, reduced proinflammatory microglial activity, and myelin formation, while S1PR5 signaling assists mature oligodendrocyte survival [149]. A multiple S1PRs modulator, fingolimod, is shown to elevate neurotrophic factors including BDNF and GDNF in cultured microglia, and to promote regulatory polarization while inhibiting the proinflammatory property of microglia in an ischemic model $[150,151]$. In mice with collagenase induced ICH, 4 weeks of fingolimod treatment post-injury significantly improves white matter integrity, neuronal survival, and functional performance at 28 days without altering lesion volume at 5 days [152], which implies that fingolimod facilitates tissue repair in the later phase. It would be reasonable to hypothesize that S1PRs modulators may contribute to regenerative processes including neurogenesis and remyelination after $\mathrm{ICH}$, but direct evidence is lacking. Although many data show that S1PR modulators improve functional recovery in different ICH models, the studies have focused on inhibition of harmful neuroinflammation [39,153-155] that can lead to secondary improvement. A proof-of-concept clinical study documented reduced perihematomal edema and better functional recovery after oral administration of fingolimod for three days post-onset comparing to patients with standard care [156].

Siponimod is a selective S1PR modulator predominantly binding to S1PR1 and S1PR5 [149], which may generate more protective effects and a less adverse reaction in ICH. The therapeutic effects of siponimod have been demonstrated in both collagenase and au- 
tologous blood models of ICH, but these studies did not address tissue repair [144,157,158]. A phase II randomized, placebo-controlled, double-blind clinical trial of siponimod in ICH patients is ongoing but temporarily suspended due to COVID-19.

Lithium, a mood stabilizer for bipolar disorders [159], was recently shown to be beneficial in preclinical ICH. Intraperitoneal administration of lithium chloride immediately after ICH induction promotes the "M2"-like polarization of microglia with enhanced phagocytosis and hematoma resolution within first 7 days post-injury; elevated levels of VEGF and BDNF that may contribute to angiogenesis and neurogenesis are documented in the subsequent 7 days [160]. Lithium has also been found to alleviate white matter injury including demyelination, axonal degeneration, and death of oligodendrocytes in the autologous blood ICH model, correspondent with upregulated BDNF level [161]; it is uncertain whether lithium chloride promotes white matter repair or protects from injury.

CD47, an integrin-associated protein expressed on erythrocytes, has been demonstrated to regulate hematoma clearance in the ICH model [162]. A blocking antibody to CD47 improves behavioral performance while reducing lesion volume by boosting M/M-induced erythrophagocytosis after experimental ICH [56,163].

Neurotrophins are essential and beneficial for tissue repair after brain injury, but exogenous neurotrophic factors are hard to sustain at a therapeutic concentration in the lesion area; chemical modifications may resolve this problem. Brain-derived neurotrophic factor (BDNF) fused to a collagen-binding domain could stimulate neurogenesis and angiogenesis better than natural BDNF and it maintains the growth factor at a higher level in the injured hemisphere after injection into the lateral ventricle of rats with ICH [164]. Exogenous fibrin-binding domain fused BDNF is observed to concentrate in the perihematomal area and to promote neural regeneration with ameliorated neurological deficits [165]. Moreover, there is a proof-of-concept study that administration of mouse nerve growth factor improves 3 month functional recovery compared to citicoline controls in patients with spontaneous ICH [166].

Besides pharmaceutical methods, many other strategies with potential to promote tissue repair and functional recovery after ICH in preclinical studies or clinical trials have been proposed (Table 1). Here we summarize these promising non-medication treatments and their possible mechanisms in promoting tissue repair after hemorrhagic stroke to provide information for further research and translation.

Table 1. Potential strategies to promote tissue regeneration after intracerebral hemorrhage.

\begin{tabular}{|c|c|c|}
\hline Approaches & & Possible Benefits \\
\hline Medications & $\begin{array}{c}\text { Statins } \\
\text { Minocycline } \\
\text { Fingolimod/Siponimod } \\
\text { Lithium } \\
\text { CD47 antibody }\end{array}$ & $\begin{array}{l}\text { Neurogenesis, angiogenesis, phagocytosis } \\
\text { "M2" polarization, neurogenesis } \\
\text { Neurogenesis, remyelination } \\
\text { Trophic factors, white matter repair } \\
\text { Hematoma clearance }\end{array}$ \\
\hline Stem cells & $\begin{array}{l}\text { BM-MSCs } \\
\text { Muse cells } \\
\text { ADSCs } \\
\text { UCSCs } \\
\text { Exosomes }\end{array}$ & $\begin{array}{c}\text { Axonal regeneration, BBB reconstruction } \\
\text { Cell replacement of neurons } \\
\text { Neuron-like differentiation, VEGF } \\
\text { Neurogenesis, angiogenesis, remyelination } \\
\text { Remyelination, axonal sprouting, neurogenesis }\end{array}$ \\
\hline Biomaterials & $\begin{array}{l}\text { Hydrogel } \\
\text { SAPNS }\end{array}$ & $\begin{array}{l}\text { Regulatory polarization, neurogenesis } \\
\text { Oligodendrogenesis, remyelination }\end{array}$ \\
\hline Rehabilitation & $\begin{array}{l}\text { Skilled reach training } \\
\text { Enriched environment } \\
\text { Acrobatic training } \\
\text { Aerobic training }\end{array}$ & $\begin{array}{l}\text { Dendritic reorganization, BDNF } \\
\text { Dendritic length } \\
\text { Neuronal activity, synaptic remodeling } \\
\text { Dendritic length and complexity }\end{array}$ \\
\hline
\end{tabular}




\subsection{Stem Cell Therapy}

As a promising strategy to improve the dismal prognosis, stem cells and related therapies remain popular in the realm of ICH research, and they have safety and improved functional outcomes in several clinical trials [167-170]. The therapeutic effects of stem cells could mainly be attributed to cell replacement proliferation and differentiation to neurons or glial cells, and/or the paracrine secretion of multiple neurotrophins and regulatory molecules [171-173] to assist immunoregulation, neural cell survival, and tissue repair, after CNS injury [174-177]. In preclinical studies, the administration of different types of stem cells or their products is observed to promote neural regeneration and recovery.

Mesenchymal stem cells (MSCs) are the most widely used cell type in research of ICH treatment [178]; they reduce lesion volume and inflammation while increasing angiogenesis, tissue repair, and functional recovery in different animal models of ICH [179]. Bonemarrow-derived mesenchymal stem cell (BMSC) transplants proliferate and differentiate into neural cells and increases the level of BDNF after collagenase induced ICH [180]. Axonal sprouting and regeneration, and improved functional recovery, are enhanced by transplantation in the same model [181]. In the hemoglobin-induced ICH model, BMSC grafts increase $\mathrm{NeuN}^{+}$(marker of mature neuron) cells and upregulate ZO-1 (a part of tight junction) expression as well as decreasing inflammatory response [182]. BM-MSCs are also observed to promote axonal regeneration in the autologous blood ICH model, which might be mediated by activating ERK1/2 and PI3K/Akt signaling pathways [183].

Some researchers have tried to facilitate the therapeutic effects of stem cells by genetic manipulation. Glial cell line-derived neurotrophic factor (GDNF) plays a crucial role in differentiation, survival, and repair in CNS [184-186]. GDNF transfected MSCs express neural cell-specific biomarkers including NSE, MAP2, and GFAP after implantation into ICH rats which leads to better behavioral performance than parental MSCs [187]. Moreover, overexpression of microRNA-126a-3p in BM-MSCs appears to repair the blood-brain barrier by differentiating to $\mathrm{CD} 31^{+}$endothelial cells and upregulating $\mathrm{ZO}-1$ and claudin-5 (both tight junction proteins) after ICH in rats [188].

Multi-lineage differentiating stress enduring (Muse) cell, a novel type of non-tumorigenic pluripotent stem cell, shows high potential for tissue regeneration and lesional navigation, and can be collected from cultured mesenchymal stem cells by stage-specific embryonic antigen 3 and CD105 double-positive sorting [189-191]. In the autologous blood-induced ICH model of mice, human Muse cells administrated into the hematoma cavity 5 days after injury survived well and led to better functional recovery than MSC controls at day 69, associated with significantly higher ratio of NeuN (57\%) and MAP2 (41.6\%) [192].

Adipose-derived stem cell (ADSC) is also a member of mesenchymal stem cells. Intravenous injection of human ADSCs in the acute phase after experimental ICH results in alleviated neurological deficits during the subacute phase [193]. Cerebral ventricle administrated ADSCs are observed to differentiate into neuron-like and astrocyte-like cells and upregulate VEGF level as well as promoting neurological functions [194]. Brain edema and tissue damage are reduced by ADSCs implantation in another ICH model [195]. CX3CR1 is a receptor of the chemokine fractalkine [196-198]. Overexpression of CX3CR1 of ADSCs facilitates the migration ability of engrafted cells to the perihematomal region of $\mathrm{ICH}$ mice and improves scores in behavioral tests compared to naïve stem cells [199]. Umbilical tissue can be another resource for mesenchymal stem cells. Intravenous administration of umbilical cord-derived stem cells (UCSC) improves neurogenesis (marked by BrdU, TUJ1, DCX, NeuN and synaptophysin) and angiogenesis (marked by vWF) as well as motor functions after autologous blood injection into rat striatum [200]. In addition, intraventricular engraftment of hepatocyte growth factor transfected UCSCs 1 week after collagenase-ICH promotes tissue repair and neurological recovery by remyelination and axonal regeneration [201].

Neural stem cells (NSCs) and induced pluripotent stem cells (iPSCs) were commonly studied in ICH treatment about 10-20 years ago [178]. A result published in 2003 showed that intravenous administration of human NSCs one day after collagenase-induced ICH in 
rodents exhibited better functional performance with injected cells migrating to the injury region where $10 \%$ differentiated to neuron-like cells, whereas $75 \%$ became glia [202]. Applying immortalized human NSCs and intracerebral delivery seems to increase neural-like differentiation (30-40\%) of engrafted cells [203]. Moreover, intracerebral transplantation of fetal neural stem cells or cell-conditioned medium both improve neurological function [204]. Intracerebral implantation of iPSCs promotes functional recovery and reduces neuronal death after experimental ICH, but engrafted cells predominantly differentiate to GFAP positive astrocytes [205]; conversely, human iPSCs derived neuroepithelial-like stem cells mature and transform into neurons in the post-ICH microenvironment [206].

Disadvantages of iPSCs include high tumorigenic risks [207], and NSCs may be harder to prepare and proliferate than other stem cell populations, which could be the reason why they are not that popular in ICH research today. Recently, stem cell-derived exosomes, the main component of therapeutic paracrine mechanisms, which contain proteins, RNAs, and lipids that might mediate tissue repair and immunomodulation after CNS injury, are attracting more interest $[208,209]$. In preclinical studies of ICH, intravenous administration of MSC-derived exosomes dramatically promotes white matter repair, axonal sprouting, and functional restoration [210]. Another study reports that injection of proteins from MSCderived exosomes increased myelin coverage and endothelial cells in the perihematomal area as well as neuroblasts and mature neurons in the subventricular zone after blood injection induced $\mathrm{ICH}$; both cognitive and sensorimotor function are restored by the treatment [211]. Furthermore, exosomes derived from genetic modified MSCs also promote functional recovery and neural survival [212,213].

Exosomes are easier to prepare and store in large amounts and have a lower potential for tumorgenicity, immunogenicity, and thrombosis than stem cells, making them more feasible in clinical application. However, their therapeutic effects might be restricted because exosomes cannot play a part in direct tissue replacement that may be crucial in regeneration after ICH. In general, stem cells and their products are highly promising for translation and improve the dismal prognosis of $\mathrm{ICH}$, but challenges include safety, type, timepoint, dosage, and mode of delivery.

\subsection{Biomaterials and Nanoparticles}

The interdisciplinary cooperation between material science and medicine has become common, including for ICH. Hydrogel is considered a biocompatible material that can be injected during minimally invasive surgery and form a matrix for cell infiltration and adhesion to facilitate tissue repair after stroke [214,215]. Gelatin hydrogel injection into the lesion three days post collagenase-induced ICH is reported to alleviate neurological deficits of mice due to conversion of $\mathrm{M} / \mathrm{M}$ from pro-inflammatory to regulatory [216]. Moreover, hydrogels may carry medications, neurotrophic factors, and stem cells as well as receive chemical modifications to enhance therapeutic effects [215,217]. Hydrogel containing epidermal growth factor (EGF) significantly increases the number of neural precursor cells (nestin-positive) around the lesion of ICH rats compared to hydrogel or EGF alone, with some of the cells differentiating to $\mathrm{TUJ} 1^{+}$neurons; neurological recovery is better in the EGF-hydrogel group [218]. Self-assembling peptide nanofiber scaffolds (SAPNS) can eventually become hydrogels after delivery and promote wound healing [219].

RADA16-I is a type of SAPNS that after injection combined with hematoma aspiration improves functional recovery in experimental ICH but almost no neurons or nerve fibers were found in the matrix [220]; a modification was made to alter its acid property to neutral, which led to nerve fibers growing within and better behavioral performance [221]. Intravenous administration of ceria nanoparticles aids OPCs proliferation, maturation, and remyelination in the collagenase model; $\mathrm{EdU}^{+} \mathrm{CC}^{+}$(proliferated mature OLs) and $\mathrm{Oligo}^{+} \mathrm{CC}^{+}$(mature OL lineage cell) cell counting is elevated at 7 days after injury compared to vehicle treatment, while MBP positive area and thickness of myelin sheath are increased at 21 days [222]. 


\subsection{Rehabilitation Training}

Rehabilitation has been widely used for decades to improve patients' functional recovery after ICH and shown stable efficacy [223,224]. Growing evidence from clinical trials and a cohort study suggest that rehabilitation should be implemented as early as possible and continue for a more extended period [225-228]. However, the method of post-ICH rehabilitation has followed the same pattern of ischemic stroke in clinical practice. The data from preclinical studies may give us inspiration for ICH specific rehabilitation. Skilled reach training requires animals to reach food through a narrow gap with one forelimb, which promotes astrocyte process growth, dendritic reorganization, and BDNF level, as well as improving sensorimotor functions in the collagenase induced ICH model $[229,230]$. An enriched environment contains tunnels, toys, and others to provide animals with multiple forms of sensory stimulation and more opportunities for physical activity, which not only improves functional recovery but also increases the dendritic length and reduces lesion volume and neuronal death after experimental ICH when combined with skilled reach training [231-234]. Acrobatic training provides a route that includes various types of barriers for mice to walk through repeatedly; motor function and coordinated movement ability are significantly restored after training in the collagenase model, and enhanced neuronal activity and synaptic remodeling are also observed [235]. Application of treadmill running, a type of aerobic training on post-ICH animals, induces longer dendritic length, complexity, and lower motor deficits [236]. Although some results suggest that rehabilitation may reduce lesion or cell death, most of the mechanisms elucidated in preclinical studies are related to neuronal or synaptic plasticity, partially attributed to astroglial activity. Recently, some innovative techniques of rehabilitation have emerged in clinical studies of ICH. Vagus nerve stimulation added to rehabilitative training prompts a much higher rate of functional recovery than patients of the rehabilitation-only group [237]. A clinical trial for robot-assisted therapy displays ameliorated neurological deficits of stroke (ICH included) patients compared with the non-physical trained group but not with patients accepted for intensive rehabilitation [238]. Nevertheless, more beneficial attempts are encouraged and necessary to alleviate disability after ICH by exploring advanced technology and task designs that may be distinctive for hemorrhagic stroke due to different anatomical predilection and pathophysiology from ischemic stroke.

\section{Conclusions and the Future}

The advances of minimally invasive surgery have contributed meaningfully to ameliorate the poor outcome of patients with supratentorial cerebral hemorrhage [239]. Moreover, immunotherapy targeting neuroinflammation seems very promising to alleviate $\mathrm{ICH}$ induced secondary brain injury. Despite this, most of the interventions have displayed safety without efficacy according to available clinical trial results [8]. Moreover, hemorrhagic stroke shows a significantly younger trend in developing countries, and the prognosis remains very undesirable $[240,241]$. More attention must be devoted to research on regaining functions such as through neural cell repopulation and axonal remyelination. There is good evidence for brain repair after human ICH, so it is realistic to promote this reparative process. However, research on the regenerative process in ICH patients remains rare and approaches have been restricted to the short period after onset and have only focused on neurogenesis. It would be imperative to extend comprehensive regenerative studies to the later periods post-ICH. Although several unknowns remain, what we do know is that neuroinflammation, particularly microglial activity, is intimately related to post-ICH restoration, so eliciting the regulatory/reparative phenotype of these cells could be a target for manipulation. With respect to fostering regeneration, drugs and bioactive substances may be easier for translation but the precise dosage, usage, and timepoint of drug treatment must be investigated to optimize its therapeutic effects during the reparative stage of ICH. Stem cell therapies are powerful tools on promoting recovery as they can repair injured tissue directly by cell replacement and/or facilitate endogenous repair by paracrine mechanisms. However, it would take some time before high-quality large 
multi-center clinical trials of stem cell treatment in ICH can occur due to concerns about safety and ethics, while the difficulty of preparation of cells is another barrier.

Since intracerebral hemorrhage is a complex intractable disease with intricate pathology, an integrated strategy for treatment deserves consideration. It would be worthwhile to imagine that the disastrous outcomes of $\mathrm{ICH}$ can be reversed in the future when stem cells are implanted into the cavity of a patient's brain after minimally invasive surgery followed by potent pro-regenerative drugs and immunomodulators, as well as choreographed rehabilitation tasks.

Author Contributions: All authors contributed equally to the preparation of this manuscript. All authors have read and agreed to the published version of the manuscript.

Funding: The authors' research is funded by operating grant support from the National Natural Science Foundation of China (grants no: 81870942, 81471174 and 81520108011), National Key Research and Development Program of China (grant no: 2018YFC1312200), and Innovation Scientists and Technicians Troop Constructions Projects of Henan Province of China (for M.X.), and from the Canadian Institutes of Health Sciences (V.W.Y.).

Conflicts of Interest: The authors declare no conflict of interest.

\section{References}

1. Cordonnier, C.; Demchuk, A.; Ziai, W.; Anderson, C.S. Intracerebral haemorrhage: Current approaches to acute management. Lancet 2018, 392, 1257-1268. [CrossRef]

2. van Asch, C.J.; Luitse, M.J.; Rinkel, G.J.; van der Tweel, I.; Algra, A.; Klijn, C.J. Incidence, case fatality, and functional outcome of intracerebral haemorrhage over time, according to age, sex, and ethnic origin: A systematic review and meta-analysis. Lancet Neurol. 2010, 9, 167-176. [CrossRef]

3. Kang, D.W. Intracerebral Hemorrhage: Large Disease Burden but Less Therapeutic Progress. J. Stroke 2017, 19, 1-2. [CrossRef]

4. An, S.J.; Kim, T.J.; Yoon, B.W. Epidemiology, Risk Factors, and Clinical Features of Intracerebral Hemorrhage: An Update. J. Stroke 2017, 19, 3-10. [CrossRef]

5. Xia, Z.; Wu, X.; Li, J.; Liu, Z.; Chen, F.; Zhang, L.; Zhang, H.; Wan, X.; Cheng, Q. Minimally Invasive Surgery is Superior to Conventional Craniotomy in Patients with Spontaneous Supratentorial Intracerebral Hemorrhage: A Systematic Review and Meta-Analysis. World Neurosurg. 2018, 115, 266-273. [CrossRef]

6. Scaggiante, J.; Zhang, X.; Mocco, J.; Kellner, C.P. Minimally Invasive Surgery for Intracerebral Hemorrhage. Stroke 2018, 49, 2612-2620. [CrossRef]

7. Hanley, D.F.; Thompson, R.E.; Rosenblum, M.; Yenokyan, G.; Lane, K.; McBee, N.; Mayo, S.W.; Bistran-Hall, A.J.; Gandhi, D.; Mould, W.A.; et al. Efficacy and safety of minimally invasive surgery with thrombolysis in intracerebral haemorrhage evacuation (MISTIE III): A randomised, controlled, open-label, blinded endpoint phase 3 trial. Lancet 2019, 393, 1021-1032. [CrossRef]

8. Xue, M.; Yong, V.W. Neuroinflammation in intracerebral haemorrhage: Immunotherapies with potential for translation. Lancet Neurol. 2020, 19, 1023-1032. [CrossRef]

9. Chen, M.; Zheng, B. Axon plasticity in the mammalian central nervous system after injury. Trends Neurosci. 2014, 37, 583-593. [CrossRef] [PubMed]

10. Emery, D.L.; Royo, N.C.; Fischer, I.; Saatman, K.E.; McIntosh, T.K. Plasticity following injury to the adult central nervous system: Is recapitulation of a developmental state worth promoting? J. Neurotrauma 2003, 20, 1271-1292. [CrossRef] [PubMed]

11. Taupin, P. Adult neurogenesis and neuroplasticity. Restor. Neurol. Neurosci. 2006, 24, 9-15. [PubMed]

12. Stangel, M.; Kuhlmann, T.; Matthews, P.M.; Kilpatrick, T.J. Achievements and obstacles of remyelinating therapies in multiple sclerosis. Nat. Rev. Neurol. 2017, 13, 742-754. [CrossRef] [PubMed]

13. Behrendt, G.; Baer, K.; Buffo, A.; Curtis, M.A.; Faull, R.L.; Rees, M.I.; Gotz, M.; Dimou, L. Dynamic changes in myelin aberrations and oligodendrocyte generation in chronic amyloidosis in mice and men. Glia 2013, 61, 273-286. [CrossRef]

14. Wang, F.; Ren, S.Y.; Chen, J.F.; Liu, K.; Li, R.X.; Li, Z.F.; Hu, B.; Niu, J.Q.; Xiao, L.; Chan, J.R.; et al. Myelin degeneration and diminished myelin renewal contribute to age-related deficits in memory. Nat. Neurosci. 2020, 23, 481-486. [CrossRef]

15. Uyeda, A.; Muramatsu, R. Molecular Mechanisms of Central Nervous System Axonal Regeneration and Remyelination: A Review. Int. J. Mol. Sci. 2020, 21, 8116. [CrossRef] [PubMed]

16. Reuter, H.; Vogg, M.C.; Serras, F. Repair, regenerate and reconstruct: Meeting the state-of-the-art. Development 2019, 146, dev176974. [CrossRef]

17. Ming, G.L.; Song, H. Adult neurogenesis in the mammalian central nervous system. Annu Rev. Neurosci. 2005, 28, 223-250. [CrossRef]

18. Qureshi, A.I.; Mendelow, A.D.; Hanley, D.F. Intracerebral haemorrhage. Lancet 2009, 373, 1632-1644. [CrossRef]

19. Askenase, M.H.; Sansing, L.H. Stages of the Inflammatory Response in Pathology and Tissue Repair after Intracerebral Hemorrhage. Semin. Neurol. 2016, 36, 288-297. [CrossRef] [PubMed] 
20. Masuda, T.; Isobe, Y.; Aihara, N.; Furuyama, F.; Misumi, S.; Kim, T.S.; Nishino, H.; Hida, H. Increase in neurogenesis and neuroblast migration after a small intracerebral hemorrhage in rats. Neurosci. Lett. 2007, 425, 114-119. [CrossRef]

21. Xu, X.; Zhang, J.; Chen, X.; Liu, J.; Lu, H.; Yang, P.; Xiao, X.; Zhao, L.; Jiao, Q.; Zhao, B.; et al. The increased expression of metabotropic glutamate receptor 5 in subventricular zone neural progenitor cells and enhanced neurogenesis in a rat model of intracerebral hemorrhage. Neuroscience 2012, 202, 474-483. [CrossRef] [PubMed]

22. Otero, L.; Zurita, M.; Bonilla, C.; Rico, M.A.; Aguayo, C.; Rodriguez, A.; Vaquero, J. Endogenous neurogenesis after intracerebral hemorrhage. Histol. Histopathol. 2012, 27, 303-315. [CrossRef] [PubMed]

23. Mino, M.; Kamii, H.; Fujimura, M.; Kondo, T.; Takasawa, S.; Okamoto, H.; Yoshimoto, T. Temporal changes of neurogenesis in the mouse hippocampus after experimental subarachnoid hemorrhage. Neurol. Res. 2003, 25, 839-845. [CrossRef] [PubMed]

24. Hostettler, I.C.; Seiffge, D.J.; Werring, D.J. Intracerebral hemorrhage: An update on diagnosis and treatment. Expert Rev. Neurother. 2019, 19, 679-694. [CrossRef]

25. Qureshi, A.I.; Tuhrim, S.; Broderick, J.P.; Batjer, H.H.; Hondo, H.; Hanley, D.F. Spontaneous intracerebral hemorrhage. N. Engl. J. Med. 2001, 344, 1450-1460. [CrossRef] [PubMed]

26. Feigin, V.L.; Forouzanfar, M.H.; Krishnamurthi, R.; Mensah, G.A.; Connor, M.; Bennett, D.A.; Moran, A.E.; Sacco, R.L.; Anderson, L.; Truelsen, T.; et al. Global and regional burden of stroke during 1990-2010: Findings from the Global Burden of Disease Study 2010. Lancet 2014, 383, 245-254. [CrossRef]

27. Hu, Y.Z.; Wang, J.W.; Luo, B.Y. Epidemiological and clinical characteristics of 266 cases of intracerebral hemorrhage in Hangzhou, China. J. Zhejiang Univ. Sci. B 2013, 14, 496-504. [CrossRef]

28. Wasserman, J.K.; Schlichter, L.C. White matter injury in young and aged rats after intracerebral hemorrhage. Exp. Neurol. 2008, 214, 266-275. [CrossRef]

29. Puig, J.; Blasco, G.; Terceno, M.; Daunis, I.E.P.; Schlaug, G.; Hernandez-Perez, M.; Cuba, V.; Carbo, G.; Serena, J.; Essig, M.; et al. Predicting Motor Outcome in Acute Intracerebral Hemorrhage. AJNR Am. J. Neuroradiol. 2019, 40, 769-775. [CrossRef]

30. Plemel, J.R.; Liu, W.Q.; Yong, V.W. Remyelination therapies: A new direction and challenge in multiple sclerosis. Nat. Rev. Drug Discov. 2017, 16, 617-634. [CrossRef]

31. Joseph, M.J.; Caliaperumal, J.; Schlichter, L.C. After Intracerebral Hemorrhage, Oligodendrocyte Precursors Proliferate and Differentiate Inside White-Matter Tracts in the Rat Striatum. Transl. Stroke Res. 2016, 7, 192-208. [CrossRef] [PubMed]

32. Keep, R.F.; Zhou, N.; Xiang, J.; Andjelkovic, A.V.; Hua, Y.; Xi, G. Vascular disruption and blood-brain barrier dysfunction in intracerebral hemorrhage. Fluids Barriers CNS 2014, 11, 18. [CrossRef] [PubMed]

33. Keep, R.F.; Xiang, J.; Ennis, S.R.; Andjelkovic, A.; Hua, Y.; Xi, G.; Hoff, J.T. Blood-brain barrier function in intracerebral hemorrhage. Acta Neurochir. Suppl. 2008, 105, 73-77. [CrossRef] [PubMed]

34. Tang, T.; Liu, X.J.; Zhang, Z.Q.; Zhou, H.J.; Luo, J.K.; Huang, J.F.; Yang, Q.D.; Li, X.Q. Cerebral angiogenesis after collagenaseinduced intracerebral hemorrhage in rats. Brain Res. 2007, 1175, 134-142. [CrossRef] [PubMed]

35. Shen, J.; Xie, L.; Mao, X.; Zhou, Y.; Zhan, R.; Greenberg, D.A.; Jin, K. Neurogenesis after primary intracerebral hemorrhage in adult human brain. J. Cereb. Blood Flow Metab. 2008, 28, 1460-1468. [CrossRef]

36. Stepien, T.; Tarka, S.; Chutoranski, D.; Felczak, P.; Acewicz, A.; Wierzba-Bobrowicz, T. Neurogenesis in adult human brain after hemorrhage and ischemic stroke. Folia Neuropathol. 2018, 56, 293-300. [CrossRef] [PubMed]

37. Sgubin, D.; Aztiria, E.; Perin, A.; Longatti, P.; Leanza, G. Activation of endogenous neural stem cells in the adult human brain following subarachnoid hemorrhage. J. Neurosci. Res. 2007, 85, 1647-1655. [CrossRef]

38. Bai, Q.; Xue, M.; Yong, V.W. Microglia and macrophage phenotypes in intracerebral haemorrhage injury: Therapeutic opportunities. Brain 2020, 143, 1297-1314. [CrossRef]

39. Tschoe, C.; Bushnell, C.D.; Duncan, P.W.; Alexander-Miller, M.A.; Wolfe, S.Q. Neuroinflammation after Intracerebral Hemorrhage and Potential Therapeutic Targets. J. Stroke 2020, 22, 29-46. [CrossRef]

40. Emsley, H.C.; Tyrrell, P.J. Inflammation and infection in clinical stroke. J. Cereb. Blood Flow Metab. 2002, 22, 1399-1419. [CrossRef]

41. Shtaya, A.; Bridges, L.R.; Esiri, M.M.; Lam-Wong, J.; Nicoll, J.A.R.; Boche, D.; Hainsworth, A.H. Rapid neuroinflammatory changes in human acute intracerebral hemorrhage. Ann. Clin. Transl. Neurol. 2019, 6, 1465-1479. [CrossRef] [PubMed]

42. Wang, J.; Dore, S. Heme oxygenase-1 exacerbates early brain injury after intracerebral haemorrhage. Brain 2007, 130, 1643-1652. [CrossRef]

43. Xue, M.; Del Bigio, M.R. Intracerebral injection of autologous whole blood in rats: Time course of inflammation and cell death. Neurosci. Lett. 2000, 283, 230-232. [CrossRef]

44. Xue, M.; Del Bigio, M.R. Immune pre-activation exacerbates hemorrhagic brain injury in immature mouse brain. J. Neuroimmunol. 2005, 165, 75-82. [CrossRef]

45. Chen, S.; Zhao, L.; Sherchan, P.; Ding, Y.; Yu, J.; Nowrangi, D.; Tang, J.; Xia, Y.; Zhang, J.H. Activation of melanocortin receptor 4 with RO27-3225 attenuates neuroinflammation through AMPK/JNK/p38 MAPK pathway after intracerebral hemorrhage in mice. J. Neuroinflammation 2018, 15, 106. [CrossRef] [PubMed]

46. Zhang, Z.; Liu, Y.; Huang, Q.; Su, Y.; Zhang, Y.; Wang, G.; Li, F. NF-kappaB activation and cell death after intracerebral hemorrhage in patients. Neurol. Sci. 2014, 35, 1097-1102. [CrossRef] [PubMed]

47. Li, M.; Li, Z.; Ren, H.; Jin, W.N.; Wood, K.; Liu, Q.; Sheth, K.N.; Shi, F.D. Colony stimulating factor 1 receptor inhibition eliminates microglia and attenuates brain injury after intracerebral hemorrhage. J. Cereb. Blood Flow Metab. 2017, 37, 2383-2395. [CrossRef] 
48. Yong, H.Y.F.; Rawji, K.S.; Ghorbani, S.; Xue, M.; Yong, V.W. The benefits of neuroinflammation for the repair of the injured central nervous system. Cell Mol. Immunol. 2019, 16, 540-546. [CrossRef] [PubMed]

49. Lloyd, A.F.; Miron, V.E. The pro-remyelination properties of microglia in the central nervous system. Nat. Rev. Neurol. 2019, 15, 447-458. [CrossRef]

50. Yang, J.; Ding, S.; Huang, W.; Hu, J.; Huang, S.; Zhang, Y.; Zhuge, Q. Interleukin-4 Ameliorates the Functional Recovery of Intracerebral Hemorrhage Through the Alternative Activation of Microglia/Macrophage. Front. Neurosci. 2016, 10, 61. [CrossRef]

51. Chang, C.F.; Wan, J.; Li, Q.; Renfroe, S.C.; Heller, N.M.; Wang, J. Alternative activation-skewed microglia/macrophages promote hematoma resolution in experimental intracerebral hemorrhage. Neurobiol. Dis. 2017, 103, 54-69. [CrossRef] [PubMed]

52. Zhao, X.; Sun, G.; Ting, S.M.; Song, S.; Zhang, J.; Edwards, N.J.; Aronowski, J. Cleaning up after ICH: The role of Nrf2 in modulating microglia function and hematoma clearance. J. Neurochem. 2015, 133, 144-152. [CrossRef] [PubMed]

53. Lin, L.; Yihao, T.; Zhou, F.; Yin, N.; Qiang, T.; Haowen, Z.; Qianwei, C.; Jun, T.; Yuan, Z.; Gang, Z.; et al. Inflammatory Regulation by Driving Microglial M2 Polarization: Neuroprotective Effects of Cannabinoid Receptor-2 Activation in Intracerebral Hemorrhage. Front. Immunol. 2017, 8, 112. [CrossRef]

54. Min, H.; Jang, Y.H.; Cho, I.H.; Yu, S.W.; Lee, S.J. Alternatively activated brain-infiltrating macrophages facilitate recovery from collagenase-induced intracerebral hemorrhage. Mol. Brain 2016, 9, 42. [CrossRef] [PubMed]

55. Li, X.; Zhu, Z.; Gao, S.; Zhang, L.; Cheng, X.; Li, S.; Li, M. Inhibition of fibrin formation reduces neuroinflammation and improves long-term outcome after intracerebral hemorrhage. Int. Immunopharmacol. 2019, 72, 473-478. [CrossRef] [PubMed]

56. Jing, C.; Bian, L.; Wang, M.; Keep, R.F.; Xi, G.; Hua, Y. Enhancement of Hematoma Clearance With CD47 Blocking Antibody in Experimental Intracerebral Hemorrhage. Stroke 2019, 50, 1539-1547. [CrossRef] [PubMed]

57. Zhang, Z.; Zhang, Z.; Lu, H.; Yang, Q.; Wu, H.; Wang, J. Microglial Polarization and Inflammatory Mediators After Intracerebral Hemorrhage. Mol. Neurobiol. 2017, 54, 1874-1886. [CrossRef]

58. Ren, H.; Han, R.; Chen, X.; Liu, X.; Wan, J.; Wang, L.; Yang, X.; Wang, J. Potential therapeutic targets for intracerebral hemorrhageassociated inflammation: An update. J. Cereb. Blood Flow Metab. 2020, 40, 1752-1768. [CrossRef]

59. Neves, J.D.; Mestriner, R.G.; Netto, C.A. Astrocytes in the cerebral cortex play a role in the spontaneous motor recovery following experimental striatal hemorrhage. Neural. Regen. Res. 2018, 13, 67-68. [CrossRef]

60. Burda, J.E.; Sofroniew, M.V. Reactive gliosis and the multicellular response to CNS damage and disease. Neuron 2014, 81, 229-248. [CrossRef]

61. Hermanns, S.; Klapka, N.; Gasis, M.; Muller, H.W. The collagenous wound healing scar in the injured central nervous system inhibits axonal regeneration. Adv. Exp. Med. Biol. 2006, 557, 177-190. [CrossRef] [PubMed]

62. Liu, Z.; Li, Y.; Cui, Y.; Roberts, C.; Lu, M.; Wilhelmsson, U.; Pekny, M.; Chopp, M. Beneficial effects of gfap/vimentin reactive astrocytes for axonal remodeling and motor behavioral recovery in mice after stroke. Glia 2014, 62, 2022-2033. [CrossRef] [PubMed]

63. Hayakawa, K.; Nakano, T.; Irie, K.; Higuchi, S.; Fujioka, M.; Orito, K.; Iwasaki, K.; Jin, G.; Lo, E.H.; Mishima, K.; et al. Inhibition of reactive astrocytes with fluorocitrate retards neurovascular remodeling and recovery after focal cerebral ischemia in mice. J. Cereb. Blood Flow Metab. 2010, 30, 871-882. [CrossRef] [PubMed]

64. Nash, B.; Ioannidou, K.; Barnett, S.C. Astrocyte phenotypes and their relationship to myelination. J. Anat. 2011, $219,44-52$. [CrossRef] [PubMed]

65. Biswas, S.; Cottarelli, A.; Agalliu, D. Neuronal and glial regulation of CNS angiogenesis and barriergenesis. Development 2020, 147, dev182279. [CrossRef] [PubMed]

66. Nutma, E.; van Gent, D.; Amor, S.; Peferoen, L.A.N. Astrocyte and Oligodendrocyte Cross-Talk in the Central Nervous System. Cells 2020, 9, 600. [CrossRef] [PubMed]

67. Mackenzie, J.M.; Clayton, J.A. Early cellular events in the penumbra of human spontaneous intracerebral hemorrhage. J. Stroke Cerebrovasc. Dis. 1999, 8, 1-8. [CrossRef]

68. Gusdon, A.M.; Gialdini, G.; Kone, G.; Baradaran, H.; Merkler, A.E.; Mangat, H.S.; Navi, B.B.; Iadecola, C.; Gupta, A.; Kamel, H.; et al. Neutrophil-Lymphocyte Ratio and Perihematomal Edema Growth in Intracerebral Hemorrhage. Stroke 2017, 48, $2589-2592$. [CrossRef]

69. Lattanzi, S.; Cagnetti, C.; Provinciali, L.; Silvestrini, M. Neutrophil-to-Lymphocyte Ratio Predicts the Outcome of Acute Intracerebral Hemorrhage. Stroke 2016, 47, 1654-1657. [CrossRef]

70. Zhao, X.; Ting, S.M.; Liu, C.H.; Sun, G.; Kruzel, M.; Roy-O'Reilly, M.; Aronowski, J. Neutrophil polarization by IL-27 as a therapeutic target for intracerebral hemorrhage. Nat. Commun. 2017, 8, 602. [CrossRef]

71. Wimmer, I.; Zrzavy, T.; Lassmann, H. Neuroinflammatory responses in experimental and human stroke lesions. J. Neuroimmunol. 2018, 323, 10-18. [CrossRef]

72. Liu, S.; Liu, X.; Chen, S.; Xiao, Y.; Zhuang, W. Neutrophil-lymphocyte ratio predicts the outcome of intracerebral hemorrhage: A meta-analysis. Medicine (Baltimore) 2019, 98, e16211. [CrossRef] [PubMed]

73. Zhou, K.; Zhong, Q.; Wang, Y.C.; Xiong, X.Y.; Meng, Z.Y.; Zhao, T.; Zhu, W.Y.; Liao, M.F.; Wu, L.R.; Yang, Y.R.; et al. Regulatory $\mathrm{T}$ cells ameliorate intracerebral hemorrhage-induced inflammatory injury by modulating microglia/macrophage polarization through the IL-10/GSK3beta/PTEN axis. J. Cereb. Blood Flow Metab. 2017, 37, 967-979. [CrossRef] [PubMed]

74. Yang, Z.; Yu, A.; Liu, Y.; Shen, H.; Lin, C.; Lin, L.; Wang, S.; Yuan, B. Regulatory T cells inhibit microglia activation and protect against inflammatory injury in intracerebral hemorrhage. Int. Immunopharmacol. 2014, 22, 522-525. [CrossRef] [PubMed] 
75. Xi, G.; Keep, R.F.; Hoff, J.T. Mechanisms of brain injury after intracerebral haemorrhage. Lancet Neurol. 2006, 5, 53-63. [CrossRef]

76. Lee, K.R.; Colon, G.P.; Betz, A.L.; Keep, R.F.; Kim, S.; Hoff, J.T. Edema from intracerebral hemorrhage: The role of thrombin. J. Neurosurg. 1996, 84, 91-96. [CrossRef]

77. Yang, S.; Song, S.; Hua, Y.; Nakamura, T.; Keep, R.F.; Xi, G. Effects of thrombin on neurogenesis after intracerebral hemorrhage. Stroke 2008, 39, 2079-2084. [CrossRef] [PubMed]

78. Zhou, H.J.; Tang, T.; Cui, H.J.; Yang, A.L.; Luo, J.K.; Lin, Y.; Yang, Q.D.; Li, X.Q. Thrombin-triggered angiogenesis in rat brains following experimental intracerebral hemorrhage. J. Neurosurg. 2012, 117, 920-928. [CrossRef] [PubMed]

79. Hua, Y.; Keep, R.F.; Gu, Y.; Xi, G. Thrombin and brain recovery after intracerebral hemorrhage. Stroke 2009, 40, S88-S89. [CrossRef] [PubMed]

80. Tarzami, S.T.; Wang, G.; Li, W.; Green, L.; Singh, J.P. Thrombin and PAR-1 stimulate differentiation of bone marrow-derived endothelial progenitor cells. J. Thromb. Haemost. 2006, 4, 656-663. [CrossRef]

81. Tsopanoglou, N.E.; Maragoudakis, M.E. Inhibition of angiogenesis by small-molecule antagonists of protease-activated receptor-1. Semin. Thromb. Hemost. 2007, 33, 680-687. [CrossRef]

82. Hu, E.; Hu, W.; Yang, A.; Zhou, H.; Zhou, J.; Luo, J.; Wang, Y.; Tang, T.; Cui, H. Thrombin promotes pericyte coverage by Tie2 activation in a rat model of intracerebral hemorrhage. Brain Res. 2019, 1708, 58-68. [CrossRef] [PubMed]

83. Xi, G.; Reiser, G.; Keep, R.F. The role of thrombin and thrombin receptors in ischemic, hemorrhagic and traumatic brain injury: Deleterious or protective? J. Neurochem. 2003, 84, 3-9. [CrossRef] [PubMed]

84. Power, C.; Henry, S.; Del Bigio, M.R.; Larsen, P.H.; Corbett, D.; Imai, Y.; Yong, V.W.; Peeling, J. Intracerebral hemorrhage induces macrophage activation and matrix metalloproteinases. Ann. Neurol. 2003, 53, 731-742. [CrossRef] [PubMed]

85. Yong, V.W.; Power, C.; Forsyth, P.; Edwards, D.R. Metalloproteinases in biology and pathology of the nervous system. Nat. Rev. Neurosci. 2001, 2, 502-511. [CrossRef] [PubMed]

86. Lischper, M.; Beuck, S.; Thanabalasundaram, G.; Pieper, C.; Galla, H.J. Metalloproteinase mediated occludin cleavage in the cerebral microcapillary endothelium under pathological conditions. Brain Res. 2010, 1326, 114-127. [CrossRef]

87. Xue, M.; Yong, V.W. Matrix metalloproteinases in intracerebral hemorrhage. Neurol. Res. 2008, 30, 775-782. [CrossRef] [PubMed]

88. Aronowski, J.; Zhao, X. Molecular pathophysiology of cerebral hemorrhage: Secondary brain injury. Stroke 2011, 42, 1781-1786. [CrossRef] [PubMed]

89. Xue, M.; Hollenberg, M.D.; Yong, V.W. Combination of thrombin and matrix metalloproteinase-9 exacerbates neurotoxicity in cell culture and intracerebral hemorrhage in mice. J. Neurosci. 2006, 26, 10281-10291. [CrossRef]

90. Florczak-Rzepka, M.; Grond-Ginsbach, C.; Montaner, J.; Steiner, T. Matrix metalloproteinases in human spontaneous intracerebral hemorrhage: An update. Cerebrovasc. Dis. 2012, 34, 249-262. [CrossRef]

91. Li, N.; Liu, Y.F.; Ma, L.; Worthmann, H.; Wang, Y.L.; Wang, Y.J.; Gao, Y.P.; Raab, P.; Dengler, R.; Weissenborn, K.; et al. Association of molecular markers with perihematomal edema and clinical outcome in intracerebral hemorrhage. Stroke 2013, 44, 658-663. [CrossRef]

92. Wang, J.; Tsirka, S.E. Neuroprotection by inhibition of matrix metalloproteinases in a mouse model of intracerebral haemorrhage. Brain 2005, 128, 1622-1633. [CrossRef] [PubMed]

93. Lei, C.; Lin, S.; Zhang, C.; Tao, W.; Dong, W.; Hao, Z.; Liu, M.; Wu, B. Activation of cerebral recovery by matrix metalloproteinase-9 after intracerebral hemorrhage. Neuroscience 2013, 230, 86-93. [CrossRef] [PubMed]

94. Chang, J.J.; Emanuel, B.A.; Mack, W.J.; Tsivgoulis, G.; Alexandrov, A.V. Matrix metalloproteinase-9: Dual role and temporal profile in intracerebral hemorrhage. J. Stroke Cerebrovasc. Dis. 2014, 23, 2498-2505. [CrossRef]

95. Hayakawa, K.; Mishima, K.; Nozako, M.; Hazekawa, M.; Mishima, S.; Fujioka, M.; Orito, K.; Egashira, N.; Iwasaki, K.; Fujiwara, M. Delayed treatment with minocycline ameliorates neurologic impairment through activated microglia expressing a high-mobility group box1-inhibiting mechanism. Stroke 2008, 39, 951-958. [CrossRef] [PubMed]

96. Ohnishi, M.; Katsuki, H.; Fukutomi, C.; Takahashi, M.; Motomura, M.; Fukunaga, M.; Matsuoka, Y.; Isohama, Y.; Izumi, Y.; Kume, T.; et al. HMGB1 inhibitor glycyrrhizin attenuates intracerebral hemorrhage-induced injury in rats. Neuropharmacology 2011, 61, 975-980. [CrossRef]

97. Hoshino, K.; Takeuchi, O.; Kawai, T.; Sanjo, H.; Ogawa, T.; Takeda, Y.; Takeda, K.; Akira, S. Cutting edge: Toll-like receptor 4 (TLR4)-deficient mice are hyporesponsive to lipopolysaccharide: Evidence for TLR4 as the Lps gene product. J. Immunol. 1999, 162, 3749-3752.

98. Dobrovolskaia, M.A.; Medvedev, A.E.; Thomas, K.E.; Cuesta, N.; Toshchakov, V.; Ren, T.; Cody, M.J.; Michalek, S.M.; Rice, N.R.; Vogel, S.N. Induction of in vitro reprogramming by Toll-like receptor (TLR)2 and TLR4 agonists in murine macrophages: Effects of TLR “homotolerance" versus "heterotolerance" on NF-kappa B signaling pathway components. J. Immunol. 2003, 170, 508-519. [CrossRef]

99. Herold, K.; Moser, B.; Chen, Y.; Zeng, S.; Yan, S.F.; Ramasamy, R.; Emond, J.; Clynes, R.; Schmidt, A.M. Receptor for advanced glycation end products (RAGE) in a dash to the rescue: Inflammatory signals gone awry in the primal response to stress. J. Leukoc. Biol. 2007, 82, 204-212. [CrossRef]

100. Lei, C.; Lin, S.; Zhang, C.; Tao, W.; Dong, W.; Hao, Z.; Liu, M.; Wu, B. Effects of high-mobility group box1 on cerebral angiogenesis and neurogenesis after intracerebral hemorrhage. Neuroscience 2013, 229, 12-19. [CrossRef]

101. Lei, C.; Wu, B.; Cao, T.; Zhang, S.; Liu, M. Activation of the high-mobility group box 1 protein-receptor for advanced glycation end-products signaling pathway in rats during neurogenesis after intracerebral hemorrhage. Stroke 2015, 46, 500-506. [CrossRef] 
102. Lei, C.; Zhang, S.; Cao, T.; Tao, W.; Liu, M.; Wu, B. HMGB1 may act via RAGE to promote angiogenesis in the later phase after intracerebral hemorrhage. Neuroscience 2015, 295, 39-47. [CrossRef] [PubMed]

103. Leitner, G.R.; Wenzel, T.J.; Marshall, N.; Gates, E.J.; Klegeris, A. Targeting toll-like receptor 4 to modulate neuroinflammation in central nervous system disorders. Expert Opin. Ther. Targets 2019, 23, 865-882. [CrossRef] [PubMed]

104. Wang, Y.C.; Wang, P.F.; Fang, H.; Chen, J.; Xiong, X.Y.; Yang, Q.W. Toll-like receptor 4 antagonist attenuates intracerebral hemorrhage-induced brain injury. Stroke 2013, 44, 2545-2552. [CrossRef] [PubMed]

105. Lei, C.; Wu, B.; Cao, T.; Liu, M.; Hao, Z. Brain recovery mediated by toll-like receptor 4 in rats after intracerebral hemorrhage. Brain Res. 2016, 1632, 1-8. [CrossRef]

106. Wagner, K.R.; Xi, G.; Hua, Y.; Kleinholz, M.; de Courten-Myers, G.M.; Myers, R.E. Early metabolic alterations in edematous perihematomal brain regions following experimental intracerebral hemorrhage. J. Neurosurg. 1998, 88, 1058-1065. [CrossRef]

107. Carhuapoma, J.R.; Wang, P.Y.; Beauchamp, N.J.; Keyl, P.M.; Hanley, D.F.; Barker, P.B. Diffusion-weighted MRI and proton MR spectroscopic imaging in the study of secondary neuronal injury after intracerebral hemorrhage. Stroke 2000, 31, 726-732. [CrossRef] [PubMed]

108. Schurr, A.; West, C.A.; Rigor, B.M. Lactate-supported synaptic function in the rat hippocampal slice preparation. Science 1988, 240, 1326-1328. [CrossRef] [PubMed]

109. Schurr, A. Lactate: The ultimate cerebral oxidative energy substrate? J. Cereb. Blood Flow Metab. 2006, 26, 142-152. [CrossRef]

110. Tarczyluk, M.A.; Nagel, D.A.; O’Neil, J.D.; Parri, H.R.; Tse, E.H.; Coleman, M.D.; Hill, E.J. Functional astrocyte-neuron lactate shuttle in a human stem cell-derived neuronal network. J. Cereb. Blood Flow Metab. 2013, 33, 1386-1393. [CrossRef]

111. Zhou, J.; Liu, T.; Guo, H.; Cui, H.; Li, P.; Feng, D.; Hu, E.; Huang, Q.; Yang, A.; Zhou, J.; et al. Lactate potentiates angiogenesis and neurogenesis in experimental intracerebral hemorrhage. Exp. Mol. Med. 2018, 50, 1-12. [CrossRef]

112. Marin, M.C.; Jost, C.A.; Brooks, L.A.; Irwin, M.S.; O’Nions, J.; Tidy, J.A.; James, N.; McGregor, J.M.; Harwood, C.A.; Yulug, I.G.; et al. A common polymorphism acts as an intragenic modifier of mutant p53 behaviour. Nat. Genet. 2000, 25, 47-54. [CrossRef] [PubMed]

113. Dumont, P.; Leu, J.I.; Della Pietra, A.C., 3rd; George, D.L.; Murphy, M. The codon 72 polymorphic variants of p53 have markedly different apoptotic potential. Nat. Genet. 2003, 33, 357-365. [CrossRef]

114. Bonafe, M.; Salvioli, S.; Barbi, C.; Trapassi, C.; Tocco, F.; Storci, G.; Invidia, L.; Vannini, I.; Rossi, M.; Marzi, E.; et al. The different apoptotic potential of the p53 codon 72 alleles increases with age and modulates in vivo ischaemia-induced cell death. Cell Death Differ. 2004, 11, 962-973. [CrossRef]

115. Pietsch, E.C.; Humbey, O.; Murphy, M.E. Polymorphisms in the p53 pathway. Oncogene 2006, 25, 1602-1611. [CrossRef]

116. Rodriguez, C.; Sobrino, T.; Agulla, J.; Bobo-Jimenez, V.; Ramos-Araque, M.E.; Duarte, J.J.; Gomez-Sanchez, J.C.; Bolanos, J.P.; Castillo, J.; Almeida, A. Neovascularization and functional recovery after intracerebral hemorrhage is conditioned by the Tp53 Arg72Pro single-nucleotide polymorphism. Cell Death Differ. 2017, 24, 144-154. [CrossRef] [PubMed]

117. Pias-Peleteiro, J.; Campos, F.; Castillo, J.; Sobrino, T. Endothelial progenitor cells as a therapeutic option in intracerebral hemorrhage. Neural. Regen. Res. 2017, 12, 558-561. [CrossRef] [PubMed]

118. Kamran, M.Z.; Patil, P.; Gude, R.P. Role of STAT3 in cancer metastasis and translational advances. Biomed. Res. Int 2013, 2013, 421821. [CrossRef]

119. Haitao, L.; Zhou, H. Activation of signal transducer and activator of transcription 3 signaling attenuates neurogenesis in a rat model of intracerebral hemorrhage. Turk. Neurosurg. 2018, 30, 793-798. [CrossRef]

120. Akbik, F.; Cafferty, W.B.; Strittmatter, S.M. Myelin associated inhibitors: A link between injury-induced and experience-dependent plasticity. Exp. Neurol. 2012, 235, 43-52. [CrossRef]

121. Yiu, G.; He, Z. Glial inhibition of CNS axon regeneration. Nat. Rev. Neurosci. 2006, 7, 617-627. [CrossRef] [PubMed]

122. Liu, Y.; Ma, C.; Li, H.; Shen, H.; Li, X.; Fu, X.; Wu, J.; Chen, G. Nogo-A/Pir-B/TrkB Signaling Pathway Activation Inhibits Neuronal Survival and Axonal Regeneration After Experimental Intracerebral Hemorrhage in Rats. J. Mol. Neurosci. 2019, 69, 360-370. [CrossRef] [PubMed]

123. Artavanis-Tsakonas, S.; Rand, M.D.; Lake, R.J. Notch signaling: Cell fate control and signal integration in development. Science 1999, 284, 770-776. [CrossRef] [PubMed]

124. Chen, J.; Yuan, X.Y.; Zhang, X. Intracerebral hemorrhage influences hippocampal neurogenesis and neurological function recovery via Notch1 signaling. Neuroreport 2021, 32, 489-497. [CrossRef]

125. Shao, Z.; Tu, S.; Shao, A. Pathophysiological Mechanisms and Potential Therapeutic Targets in Intracerebral Hemorrhage. Front. Pharmacol. 2019, 10, 1079. [CrossRef] [PubMed]

126. Chen, C.J.; Ding, D.; Ironside, N.; Buell, T.J.; Elder, L.J.; Warren, A.; Adams, A.P.; Ratcliffe, S.J.; James, R.F.; Naval, N.S.; et al. Statins for neuroprotection in spontaneous intracerebral hemorrhage. Neurology 2019, 93, 1056-1066. [CrossRef]

127. Powers, W.J.; Rabinstein, A.A.; Ackerson, T.; Adeoye, O.M.; Bambakidis, N.C.; Becker, K.; Biller, J.; Brown, M.; Demaerschalk, B.M.; Hoh, B.; et al. Guidelines for the Early Management of Patients With Acute Ischemic Stroke: 2019 Update to the 2018 Guidelines for the Early Management of Acute Ischemic Stroke: A Guideline for Healthcare Professionals From the American Heart Association/American Stroke Association. Stroke 2019, 50, e344-e418. [CrossRef]

128. Meschia, J.F.; Bushnell, C.; Boden-Albala, B.; Braun, L.T.; Bravata, D.M.; Chaturvedi, S.; Creager, M.A.; Eckel, R.H.; Elkind, M.S.; Fornage, M.; et al. Guidelines for the primary prevention of stroke: A statement for healthcare professionals from the American Heart Association/American Stroke Association. Stroke 2014, 45, 3754-3832. [CrossRef] 
129. Amarenco, P.; Labreuche, J. Lipid management in the prevention of stroke: Review and updated meta-analysis of statins for stroke prevention. Lancet Neurol. 2009, 8, 453-463. [CrossRef]

130. Amarenco, P.; Bogousslavsky, J.; Callahan, A., 3rd; Goldstein, L.B.; Hennerici, M.; Rudolph, A.E.; Sillesen, H.; Simunovic, L.; Szarek, M.; Welch, K.M.; et al. High-dose atorvastatin after stroke or transient ischemic attack. N. Engl. J. Med. 2006, 355, 549-559. [CrossRef]

131. McKinney, J.S.; Kostis, W.J. Statin therapy and the risk of intracerebral hemorrhage: A meta-analysis of 31 randomized controlled trials. Stroke 2012, 43, 2149-2156. [CrossRef] [PubMed]

132. Ziff, O.J.; Banerjee, G.; Ambler, G.; Werring, D.J. Statins and the risk of intracerebral haemorrhage in patients with stroke: Systematic review and meta-analysis. J. Neurol. Neurosurg. Psychiatry 2019, 90, 75-83. [CrossRef]

133. Ribe, A.R.; Vestergaard, C.H.; Vestergaard, M.; Fenger-Gron, M.; Pedersen, H.S.; Lietzen, L.W.; Brynningsen, P.K. Statins and Risk of Intracerebral Haemorrhage in a Stroke-Free Population: A Nationwide Danish Propensity Score Matched Cohort Study. EClinicalMedicine 2019, 8, 78-84. [CrossRef]

134. Tapia-Perez, H.; Sanchez-Aguilar, M.; Torres-Corzo, J.G.; Rodriguez-Leyva, I.; Gonzalez-Aguirre, D.; Gordillo-Moscoso, A.; Chalita-Williams, C. Use of statins for the treatment of spontaneous intracerebral hemorrhage: Results of a pilot study. Cent. Eur. Neurosurg. 2009, 70, 15-20. [CrossRef] [PubMed]

135. Karki, K.; Knight, R.A.; Han, Y.; Yang, D.; Zhang, J.; Ledbetter, K.A.; Chopp, M.; Seyfried, D.M. Simvastatin and atorvastatin improve neurological outcome after experimental intracerebral hemorrhage. Stroke 2009, 40, 3384-3389. [CrossRef] [PubMed]

136. Seyfried, D.; Han, Y.; Lu, D.; Chen, J.; Bydon, A.; Chopp, M. Improvement in neurological outcome after administration of atorvastatin following experimental intracerebral hemorrhage in rats. J. Neurosurg. 2004, 101, 104-107. [CrossRef] [PubMed]

137. Yang, D.; Han, Y.; Zhang, J.; Chopp, M.; Seyfried, D.M. Statins Enhance Expression of Growth Factors and Activate the PI3K/Akt-mediated Signaling Pathway after Experimental Intracerebral Hemorrhage. World J. Neurosci 2012, 2, 74-80. [CrossRef]

138. Yang, D.; Knight, R.A.; Han, Y.; Karki, K.; Zhang, J.; Ding, C.; Chopp, M.; Seyfried, D.M. Vascular recovery promoted by atorvastatin and simvastatin after experimental intracerebral hemorrhage: Magnetic resonance imaging and histological study. J. Neurosurg. 2011, 114, 1135-1142. [CrossRef] [PubMed]

139. Wang, Y.; Chen, Q.; Tan, Q.; Feng, Z.; He, Z.; Tang, J.; Feng, H.; Zhu, G.; Chen, Z. Simvastatin accelerates hematoma resolution after intracerebral hemorrhage in a PPARgamma-dependent manner. Neuropharmacology 2018, 128, 244-254. [CrossRef]

140. Wu, J.; Yang, S.; Xi, G.; Fu, G.; Keep, R.F.; Hua, Y. Minocycline reduces intracerebral hemorrhage-induced brain injury. Neurol. Res. 2009, 31, 183-188. [CrossRef]

141. Yang, H.; Gao, X.J.; Li, Y.J.; Su, J.B.; E, T.Z.; Zhang, X.; Ni, W.; Gu, Y.X. Minocycline reduces intracerebral hemorrhage-induced white matter injury in piglets. CNS Neurosci. Ther. 2019, 25, 1195-1206. [CrossRef] [PubMed]

142. Tikka, T.; Fiebich, B.L.; Goldsteins, G.; Keinanen, R.; Koistinaho, J. Minocycline, a tetracycline derivative, is neuroprotective against excitotoxicity by inhibiting activation and proliferation of microglia. J. Neurosci. 2001, 21, 2580-2588. [CrossRef] [PubMed]

143. Kobayashi, K.; Imagama, S.; Ohgomori, T.; Hirano, K.; Uchimura, K.; Sakamoto, K.; Hirakawa, A.; Takeuchi, H.; Suzumura, A.; Ishiguro, N.; et al. Minocycline selectively inhibits M1 polarization of microglia. Cell Death Dis. 2013, 4, e525. [CrossRef]

144. Sun, N.; Shen, Y.; Han, W.; Shi, K.; Wood, K.; Fu, Y.; Hao, J.; Liu, Q.; Sheth, K.N.; Huang, D.; et al. Selective Sphingosine-1Phosphate Receptor 1 Modulation Attenuates Experimental Intracerebral Hemorrhage. Stroke 2016, 47, 1899-1906. [CrossRef] [PubMed]

145. Pu, J.; Shi, W.; Wang, Z.; Wang, R.; Guo, Z.; Liu, C.; Sun, J.; Gao, L.; Zhou, R. Effects of minocycline on the expression of NGF and HSP70 and its neuroprotection role following intracerebral hemorrhage in rats. J. Biomed. Res. 2011, 25, 292-298. [CrossRef]

146. Wang, R.; Hao, D.; Shi, W.; Pu, J.; Wang, Z. Effects of minocycline on apoptosis and angiogenesis-related protein expression in a rat model of intracerebral hemorrhage. Neural. Regen. Res. 2012, 7, 595-600. [CrossRef]

147. Fouda, A.Y.; Newsome, A.S.; Spellicy, S.; Waller, J.L.; Zhi, W.; Hess, D.C.; Ergul, A.; Edwards, D.J.; Fagan, S.C.; Switzer, J.A. Minocycline in Acute Cerebral Hemorrhage: An Early Phase Randomized Trial. Stroke 2017, 48, 2885-2887. [CrossRef]

148. Chang, J.J.; Kim-Tenser, M.; Emanuel, B.A.; Jones, G.M.; Chapple, K.; Alikhani, A.; Sanossian, N.; Mack, W.J.; Tsivgoulis, G.; Alexandrov, A.V.; et al. Minocycline and matrix metalloproteinase inhibition in acute intracerebral hemorrhage: A pilot study. Eur. J. Neurol. 2017, 24, 1384-1391. [CrossRef]

149. O'Sullivan, S.; Dev, K.K. Sphingosine-1-phosphate receptor therapies: Advances in clinical trials for CNS-related diseases. Neuropharmacology 2017, 113, 597-607. [CrossRef]

150. Noda, H.; Takeuchi, H.; Mizuno, T.; Suzumura, A. Fingolimod phosphate promotes the neuroprotective effects of microglia. J. Neuroimmunol. 2013, 256, 13-18. [CrossRef]

151. Qin, C.; Fan, W.H.; Liu, Q.; Shang, K.; Murugan, M.; Wu, L.J.; Wang, W.; Tian, D.S. Fingolimod Protects Against Ischemic White Matter Damage by Modulating Microglia Toward M2 Polarization via STAT3 Pathway. Stroke 2017, 48, 3336-3346. [CrossRef]

152. Yang, Z.; Dong, S.; Zheng, Q.; Zhang, L.; Tan, X.; Zou, J.; Yan, B.; Chen, Y. FTY720 attenuates iron deposition and glial responses in improving delayed lesion and long-term outcomes of collagenase-induced intracerebral hemorrhage. Brain Res. 2019, 1718, 91-102. [CrossRef] [PubMed]

153. Li, Y.J.; Chang, G.Q.; Liu, Y.; Gong, Y.; Yang, C.; Wood, K.; Shi, F.D.; Fu, Y.; Yan, Y. Fingolimod alters inflammatory mediators and vascular permeability in intracerebral hemorrhage. Neurosci. Bull. 2015, 31, 755-762. [CrossRef] 
154. Rolland, W.B.; Lekic, T.; Krafft, P.R.; Hasegawa, Y.; Altay, O.; Hartman, R.; Ostrowski, R.; Manaenko, A.; Tang, J.; Zhang, J.H. Fingolimod reduces cerebral lymphocyte infiltration in experimental models of rodent intracerebral hemorrhage. Exp. Neurol. 2013, 241, 45-55. [CrossRef]

155. Napier, J.; Rose, L.; Adeoye, O.; Hooker, E.; Walsh, K.B. Modulating acute neuroinflammation in intracerebral hemorrhage: The potential promise of currently approved medications for multiple sclerosis. Immunopharmacol. Immunotoxicol. 2019, 41, 7-15. [CrossRef] [PubMed]

156. Fu, Y.; Hao, J.; Zhang, N.; Ren, L.; Sun, N.; Li, Y.J.; Yan, Y.; Huang, D.; Yu, C.; Shi, F.D. Fingolimod for the treatment of intracerebral hemorrhage: A 2-arm proof-of-concept study. JAMA Neurol. 2014, 71, 1092-1101. [CrossRef]

157. Bobinger, T.; Manaenko, A.; Burkardt, P.; Beuscher, V.; Sprugel, M.I.; Roeder, S.S.; Bauerle, T.; Seyler, L.; Nagel, A.M.; Linker, R.A.; et al. Siponimod (BAF-312) Attenuates Perihemorrhagic Edema And Improves Survival in Experimental Intracerebral Hemorrhage. Stroke 2019, 50, 3246-3254. [CrossRef] [PubMed]

158. Bobinger, T.; Bauerle, T.; Seyler, L.; v Horsten, S.; Schwab, S.; Huttner, H.B.; Manaenko, A. A Sphingosine-1-Phosphate Receptor Modulator Attenuated Secondary Brain Injury and Improved Neurological Functions of Mice after ICH. Oxid Med. Cell Longev. 2020, 2020, 3214350. [CrossRef]

159. Baldessarini, R.J.; Tondo, L.; Davis, P.; Pompili, M.; Goodwin, F.K.; Hennen, J. Decreased risk of suicides and attempts during long-term lithium treatment: A meta-analytic review. Bipolar. Disord. 2006, 8, 625-639. [CrossRef]

160. Li, R.; Liu, Z.; Wu, X.; Yu, Z.; Zhao, S.; Tang, X. Lithium chloride promoted hematoma resolution after intracerebral hemorrhage through GSK-3beta-mediated pathways-dependent microglia phagocytosis and M2-phenotype differentiation, angiogenesis and neurogenesis in a rat model. Brain Res. Bull. 2019, 152, 117-127. [CrossRef] [PubMed]

161. Li, M.; Xia, M.; Chen, W.; Wang, J.; Yin, Y.; Guo, C.; Li, C.; Tang, X.; Zhao, H.; Tan, Q.; et al. Lithium treatment mitigates white matter injury after intracerebral hemorrhage through brain-derived neurotrophic factor signaling in mice. Transl. Res. 2020, 217, 61-74. [CrossRef] [PubMed]

162. Ni, W.; Mao, S.; Xi, G.; Keep, R.F.; Hua, Y. Role of Erythrocyte CD47 in Intracerebral Hematoma Clearance. Stroke 2016, 47, 505-511. [CrossRef]

163. Tao, C.; Keep, R.F.; Xi, G.; Hua, Y. CD47 Blocking Antibody Accelerates Hematoma Clearance After Intracerebral Hemorrhage in Aged Rats. Transl. Stroke Res. 2020, 11, 541-551. [CrossRef] [PubMed]

164. Guan, J.; Zhang, B.; Zhang, J.; Ding, W.; Xiao, Z.; Zhu, Z.; Han, Q.; Wu, C.; Sun, Y.; Tong, W.; et al. Nerve regeneration and functional recovery by collagen-binding brain-derived neurotrophic factor in an intracerebral hemorrhage model. Tissue Eng. Part A 2015, 21, 62-74. [CrossRef] [PubMed]

165. Han, Q.Q.; Jin, W.; Xiao, Z.F.; Huang, J.C.; Ni, H.B.; Kong, J.; Wu, J.; Chen, B.; Liang, W.B.; Dai, J.W. The promotion of neurological recovery in an intracerebral hemorrhage model using fibrin-binding brain derived neurotrophic factor. Biomaterials 2011, 32, 3244-3252. [CrossRef] [PubMed]

166. An, S.; Jia, Y.; Tian, Y.; Sun, J.; Wei, Y.; Yue, S.; Lin, L.; Wei, Y.; Li, Y.; Lei, P.; et al. Mouse nerve growth factor promotes neurological recovery in patients with acute intracerebral hemorrhage: A proof-of-concept study. J. Neurol. Sci. 2020, 418, 117069. [CrossRef]

167. Chen, L.; Xi, H.; Huang, H.; Zhang, F.; Liu, Y.; Chen, D.; Xiao, J. Multiple cell transplantation based on an intraparenchymal approach for patients with chronic phase stroke. Cell Transplant. 2013, 22 (Suppl. 1), S83-S91. [CrossRef]

168. Li, Z.M.; Zhang, Z.T.; Guo, C.J.; Geng, F.Y.; Qiang, F.; Wang, L.X. Autologous bone marrow mononuclear cell implantation for intracerebral hemorrhage-a prospective clinical observation. Clin. Neurol. Neurosurg. 2013, 115, 72-76. [CrossRef]

169. Chang, Z.; Mao, G.; Sun, L.; Ao, Q.; Gu, Y.; Liu, Y. Cell therapy for cerebral hemorrhage: Five year follow-up report. Exp. Ther. Med. 2016, 12, 3535-3540. [CrossRef]

170. Tsang, K.S.; Ng, C.P.S.; Zhu, X.L.; Wong, G.K.C.; Lu, G.; Ahuja, A.T.; Wong, K.S.L.; Ng, H.K.; Poon, W.S. Phase I/II randomized controlled trial of autologous bone marrow-derived mesenchymal stem cell therapy for chronic stroke. World J. Stem. Cells 2017, 9, 133-143. [CrossRef] [PubMed]

171. Cordeiro, M.F.; Horn, A.P. Stem cell therapy in intracerebral hemorrhage rat model. World J. Stem. Cells 2015, 7, 618-629. [CrossRef] [PubMed]

172. Marsh, S.E.; Blurton-Jones, M. Neural stem cell therapy for neurodegenerative disorders: The role of neurotrophic support. Neurochem. Int. 2017, 106, 94-100. [CrossRef] [PubMed]

173. Gao, L.; Xu, W.; Li, T.; Chen, J.; Shao, A.; Yan, F.; Chen, G. Stem Cell Therapy: A Promising Therapeutic Method for Intracerebral Hemorrhage. Cell Transplant. 2018, 27, 1809-1824. [CrossRef]

174. Hsu, Y.C.; Chen, S.L.; Wang, D.Y.; Chiu, I.M. Stem cell-based therapy in neural repair. Biomed. J. 2013, 36, 98-105. [CrossRef]

175. Ryu, S.; Lee, S.H.; Kim, S.U.; Yoon, B.W. Human neural stem cells promote proliferation of endogenous neural stem cells and enhance angiogenesis in ischemic rat brain. Neural. Regen. Res. 2016, 11, 298-304. [CrossRef]

176. Giusto, E.; Donega, M.; Cossetti, C.; Pluchino, S. Neuro-immune interactions of neural stem cell transplants: From animal disease models to human trials. Exp. Neurol. 2014, 260, 19-32. [CrossRef] [PubMed]

177. Wu, K.; Zhang, R.; Lu, Y.; Wen, L.; Li, Y.; Duan, R.; Yao, Y.; Jia, Y. Lin28B regulates the fate of grafted mesenchymal stem cells and enhances their protective effects against Alzheimer's disease by upregulating IGF-2. J. Cell Physiol. 2019, 234, 21860-21876. [CrossRef] [PubMed]

178. Huang, A.P.; Hsu, Y.H.; Wu, M.S.; Tsai, H.H.; Su, C.Y.; Ling, T.Y.; Hsu, S.H.; Lai, D.M. Potential of stem cell therapy in intracerebral hemorrhage. Mol. Biol. Rep. 2020, 47, 4671-4680. [CrossRef] [PubMed] 
179. Bedini, G.; Bersano, A.; Zanier, E.R.; Pischiutta, F.; Parati, E.A. Mesenchymal Stem Cell Therapy in Intracerebral Haemorrhagic Stroke. Curr. Med. Chem. 2018, 25, 2176-2197. [CrossRef]

180. Wang, S.P.; Wang, Z.H.; Peng, D.Y.; Li, S.M.; Wang, H.; Wang, X.H. Therapeutic effect of mesenchymal stem cells in rats with intracerebral hemorrhage: Reduced apoptosis and enhanced neuroprotection. Mol. Med. Rep. 2012, 6, 848-854. [CrossRef]

181. Liang, H.; Yin, Y.; Lin, T.; Guan, D.; Ma, B.; Li, C.; Wang, Y.; Zhang, X. Transplantation of bone marrow stromal cells enhances nerve regeneration of the corticospinal tract and improves recovery of neurological functions in a collagenase-induced rat model of intracerebral hemorrhage. Mol. Cells 2013, 36, 17-24. [CrossRef]

182. Ding, R.; Lin, C.; Wei, S.; Zhang, N.; Tang, L.; Lin, Y.; Chen, Z.; Xie, T.; Chen, X.; Feng, Y.; et al. Therapeutic Benefits of Mesenchymal Stromal Cells in a Rat Model of Hemoglobin-Induced Hypertensive Intracerebral Hemorrhage. Mol. Cells 2017, 40, 133-142. [CrossRef]

183. Cui, J.; Cui, C.; Cui, Y.; Li, R.; Sheng, H.; Jiang, X.; Tian, Y.; Wang, K.; Gao, J. Bone Marrow Mesenchymal Stem Cell Transplantation Increases GAP-43 Expression via ERK1/2 and PI3K/Akt Pathways in Intracerebral Hemorrhage. Cell Physiol. Biochem. 2017, 42, 137-144. [CrossRef]

184. Kobayashi, T.; Ahlenius, H.; Thored, P.; Kobayashi, R.; Kokaia, Z.; Lindvall, O. Intracerebral infusion of glial cell line-derived neurotrophic factor promotes striatal neurogenesis after stroke in adult rats. Stroke 2006, 37, 2361-2367. [CrossRef] [PubMed]

185. Gill, S.S.; Patel, N.K.; Hotton, G.R.; O'Sullivan, K.; McCarter, R.; Bunnage, M.; Brooks, D.J.; Svendsen, C.N.; Heywood, P. Direct brain infusion of glial cell line-derived neurotrophic factor in Parkinson disease. Nat. Med. 2003, 9, 589-595. [CrossRef] [PubMed]

186. Xing, B.; Xin, T.; Zhao, L.; Hunter, R.L.; Chen, Y.; Bing, G. Glial cell line-derived neurotrophic factor protects midbrain dopaminergic neurons against lipopolysaccharide neurotoxicity. J. Neuroimmunol. 2010, 225, 43-51. [CrossRef] [PubMed]

187. Deng, L.; Gao, X.; Fan, G.; Yang, C. Effects of GDNF-Transfected Marrow Stromal Cells on Rats with Intracerebral Hemorrhage. J. Stroke Cerebrovasc. Dis. 2019, 28, 2555-2562. [CrossRef] [PubMed]

188. Wang, C.; Cao, J.; Duan, S.; Xu, R.; Yu, H.; Huo, X.; Qian, Y. Effect of MicroRNA-126a-3p on Bone Marrow Mesenchymal Stem Cells Repairing Blood-brain Barrier and Nerve Injury after Intracerebral Hemorrhage. J. Stroke Cerebrovasc. Dis. 2020, 29 , 104748. [CrossRef] [PubMed]

189. Kuroda, Y.; Kitada, M.; Wakao, S.; Nishikawa, K.; Tanimura, Y.; Makinoshima, H.; Goda, M.; Akashi, H.; Inutsuka, A.; Niwa, A.; et al. Unique multipotent cells in adult human mesenchymal cell populations. Proc. Natl. Acad. Sci. USA 2010, 107, 8639-8643. [CrossRef]

190. Wakao, S.; Kuroda, Y.; Ogura, F.; Shigemoto, T.; Dezawa, M. Regenerative Effects of Mesenchymal Stem Cells: Contribution of Muse Cells, a Novel Pluripotent Stem Cell Type that Resides in Mesenchymal Cells. Cells 2012, 1, 1045-1060. [CrossRef]

191. Cao, J.; Yang, Z.; Xiao, R.; Pan, B. Regenerative potential of pluripotent nontumorgenetic stem cells: Multilineage differentiating stress enduring cells (Muse cells). Regen. Ther. 2020, 15, 92-96. [CrossRef]

192. Shimamura, N.; Kakuta, K.; Wang, L.; Naraoka, M.; Uchida, H.; Wakao, S.; Dezawa, M.; Ohkuma, H. Neuro-regeneration therapy using human Muse cells is highly effective in a mouse intracerebral hemorrhage model. Exp. Brain Res. 2017, 235, 565-572. [CrossRef]

193. Kuramoto, Y.; Takagi, T.; Tatebayashi, K.; Beppu, M.; Doe, N.; Fujita, M.; Yoshimura, S. Intravenous administration of human adipose-derived stem cells ameliorates motor and cognitive function for intracerebral hemorrhage mouse model. Brain Res. 2019, 1711, 58-67. [CrossRef] [PubMed]

194. Chen, J.; Tang, Y.X.; Liu, Y.M.; Chen, J.; Hu, X.Q.; Liu, N.; Wang, S.X.; Zhang, Y.; Zeng, W.G.; Ni, H.J.; et al. Transplantation of adipose-derived stem cells is associated with neural differentiation and functional improvement in a rat model of intracerebral hemorrhage. CNS Neurosci. Ther. 2012, 18, 847-854. [CrossRef] [PubMed]

195. Zhang, Y.; Deng, H.; Hu, Y.; Pan, C.; Wu, G.; Li, Q.; Tang, Z. Adipose-derived mesenchymal stem cells stereotactic transplantation alleviate brain edema from intracerebral hemorrhage. J. Cell Biochem. 2019, 120, 14372-14382. [CrossRef]

196. Re, D.B.; Przedborski, S. Fractalkine: Moving from chemotaxis to neuroprotection. Nat. Neurosci. 2006, 9, 859-861. [CrossRef] [PubMed]

197. Miller, R.J.; Rostene, W.; Apartis, E.; Banisadr, G.; Biber, K.; Milligan, E.D.; White, F.A.; Zhang, J. Chemokine action in the nervous system. J. Neurosci. 2008, 28, 11792-11795. [CrossRef] [PubMed]

198. Harrison, J.K.; Jiang, Y.; Chen, S.; Xia, Y.; Maciejewski, D.; McNamara, R.K.; Streit, W.J.; Salafranca, M.N.; Adhikari, S.; Thompson, D.A.; et al. Role for neuronally derived fractalkine in mediating interactions between neurons and CX3CR1-expressing microglia. Proc. Natl. Acad. Sci. USA 1998, 95, 10896-10901. [CrossRef]

199. Li, G.; Yu, H.; Liu, N.; Zhang, P.; Tang, Y.; Hu, Y.; Zhang, Y.; Pan, C.; Deng, H.; Wang, J.; et al. Overexpression of CX3CR1 in Adipose-Derived Stem Cells Promotes Cell Migration and Functional Recovery After Experimental Intracerebral Hemorrhage. Front. Neurosci. 2019, 13, 462. [CrossRef] [PubMed]

200. Yang, D.; Han, Y.; Zhang, J.; Seyda, A.; Chopp, M.; Seyfried, D.M. Therapeutic effect of human umbilical tissue-derived cell treatment in rats with experimental intracerebral hemorrhage. Brain Res. 2012, 1444, 1-10. [CrossRef] [PubMed]

201. Liu, A.M.; Lu, G.; Tsang, K.S.; Li, G.; Wu, Y.; Huang, Z.S.; Ng, H.K.; Kung, H.F.; Poon, W.S. Umbilical cord-derived mesenchymal stem cells with forced expression of hepatocyte growth factor enhance remyelination and functional recovery in a rat intracerebral hemorrhage model. Neurosurgery 2010, 67, 357-365. [CrossRef] [PubMed]

202. Jeong, S.W.; Chu, K.; Jung, K.H.; Kim, S.U.; Kim, M.; Roh, J.K. Human neural stem cell transplantation promotes functional recovery in rats with experimental intracerebral hemorrhage. Stroke 2003, 34, 2258-2263. [CrossRef] [PubMed] 
203. Lee, H.J.; Kim, K.S.; Kim, E.J.; Choi, H.B.; Lee, K.H.; Park, I.H.; Ko, Y.; Jeong, S.W.; Kim, S.U. Brain transplantation of immortalized human neural stem cells promotes functional recovery in mouse intracerebral hemorrhage stroke model. Stem. Cells 2007, 25, 1204-1212. [CrossRef] [PubMed]

204. Wang, Z.; Cui, C.; Li, Q.; Zhou, S.; Fu, J.; Wang, X.; Zhuge, Q. Intracerebral transplantation of foetal neural stem cells improves brain dysfunction induced by intracerebral haemorrhage stroke in mice. J. Cell Mol. Med. 2011, 15, 2624-2633. [CrossRef]

205. Qin, J.; Ma, X.; Qi, H.; Song, B.; Wang, Y.; Wen, X.; Wang, Q.M.; Sun, S.; Li, Y.; Zhang, R.; et al. Transplantation of Induced Pluripotent Stem Cells Alleviates Cerebral Inflammation and Neural Damage in Hemorrhagic Stroke. PLoS ONE 2015, 10, e0129881. [CrossRef]

206. Qin, J.; Song, B.; Zhang, H.; Wang, Y.; Wang, N.; Ji, Y.; Qi, J.; Chandra, A.; Yang, B.; Zhang, Y.; et al. Transplantation of human neuro-epithelial-like stem cells derived from induced pluripotent stem cells improves neurological function in rats with experimental intracerebral hemorrhage. Neurosci. Lett. 2013, 548, 95-100. [CrossRef]

207. Yamanaka, S. Pluripotent Stem Cell-Based Cell Therapy-Promise and Challenges. Cell Stem. Cell 2020, 27, 523-531. [CrossRef]

208. Branscome, H.; Paul, S.; Yin, D.; El-Hage, N.; Agbottah, E.T.; Zadeh, M.A.; Liotta, L.A.; Kashanchi, F. Use of Stem Cell Extracellular Vesicles as a "Holistic" Approach to CNS Repair. Front. Cell Dev. Biol. 2020, 8, 455. [CrossRef]

209. Gorabi, A.M.; Kiaie, N.; Barreto, G.E.; Read, M.I.; Tafti, H.A.; Sahebkar, A. The Therapeutic Potential of Mesenchymal Stem Cell-Derived Exosomes in Treatment of Neurodegenerative Diseases. Mol. Neurobiol. 2019, 56, 8157-8167. [CrossRef]

210. Otero-Ortega, L.; Gomez de Frutos, M.C.; Laso-Garcia, F.; Rodriguez-Frutos, B.; Medina-Gutierrez, E.; Lopez, J.A.; Vazquez, J.; Diez-Tejedor, E.; Gutierrez-Fernandez, M. Exosomes promote restoration after an experimental animal model of intracerebral hemorrhage. J. Cereb. Blood Flow Metab. 2018, 38, 767-779. [CrossRef]

211. Han, Y.; Seyfried, D.; Meng, Y.; Yang, D.; Schultz, L.; Chopp, M.; Seyfried, D. Multipotent mesenchymal stromal cell-derived exosomes improve functional recovery after experimental intracerebral hemorrhage in the rat. J. Neurosurg. 2018, 131, 290-300. [CrossRef] [PubMed]

212. Duan, S.; Wang, F.; Cao, J.; Wang, C. Exosomes Derived from MicroRNA-146a-5p-Enriched Bone Marrow Mesenchymal Stem Cells Alleviate Intracerebral Hemorrhage by Inhibiting Neuronal Apoptosis and Microglial M1 Polarization. Drug Des. Devel. Ther. 2020, 14, 3143-3158. [CrossRef] [PubMed]

213. Shen, H.; Yao, X.; Li, H.; Li, X.; Zhang, T.; Sun, Q.; Ji, C.; Chen, G. Role of Exosomes Derived from miR-133b Modified MSCs in an Experimental Rat Model of Intracerebral Hemorrhage. J. Mol. Neurosci. 2018, 64, 421-430. [CrossRef] [PubMed]

214. Nih, L.R.; Carmichael, S.T.; Segura, T. Hydrogels for brain repair after stroke: An emerging treatment option. Curr. Opin. Biotechnol. 2016, 40, 155-163. [CrossRef]

215. Nih, L.R.; Gojgini, S.; Carmichael, S.T.; Segura, T. Dual-function injectable angiogenic biomaterial for the repair of brain tissue following stroke. Nat. Mater. 2018, 17, 642-651. [CrossRef] [PubMed]

216. Xu, J.; Duan, Z.; Qi, X.; Ou, Y.; Guo, X.; Zi, L.; Wei, Y.; Liu, H.; Ma, L.; Li, H.; et al. Injectable Gelatin Hydrogel Suppresses Inflammation and Enhances Functional Recovery in a Mouse Model of Intracerebral Hemorrhage. Front. Bioeng. Biotechnol. 2020, 8, 785. [CrossRef]

217. Hu, Y.; Liu, N.; Zhang, P.; Pan, C.; Zhang, Y.; Tang, Y.; Deng, H.; Aimaiti, M.; Zhang, Y.; Zhou, H.; et al. Preclinical Studies of Stem Cell Transplantation in Intracerebral Hemorrhage: A Systemic Review and Meta-Analysis. Mol. Neurobiol. 2016, 53, 5269-5277. [CrossRef]

218. Lim, T.C.; Mandeville, E.; Weng, D.; Wang, L.S.; Kurisawa, M.; Leite-Morris, K.; Selim, M.H.; Lo, E.H.; Spector, M. Hydrogel-Based Therapy for Brain Repair After Intracerebral Hemorrhage. Transl. Stroke Res. 2020, 11, 412-417. [CrossRef]

219. Schneider, A.; Garlick, J.A.; Egles, C. Self-assembling peptide nanofiber scaffolds accelerate wound healing. PLoS ONE 2008, 3, e1410. [CrossRef]

220. Sang, L.Y.; Liang, Y.X.; Li, Y.; Wong, W.M.; Tay, D.K.; So, K.F.; Ellis-Behnke, R.G.; Wu, W.; Cheung, R.T. A self-assembling nanomaterial reduces acute brain injury and enhances functional recovery in a rat model of intracerebral hemorrhage. Nanomedicine 2015, 11, 611-620. [CrossRef]

221. Zhang, N.; Luo, Y.; He, L.; Zhou, L.; Wu, W. A self-assembly peptide nanofibrous scaffold reduces inflammatory response and promotes functional recovery in a mouse model of intracerebral hemorrhage. Nanomedicine 2016, 12, 1205-1217. [CrossRef] [PubMed]

222. Zheng, J.; Lu, J.; Mei, S.; Wu, H.; Sun, Z.; Fang, Y.; Xu, S.; Wang, X.; Shi, L.; Xu, W.; et al. Ceria nanoparticles ameliorate white matter injury after intracerebral hemorrhage: Microglia-astrocyte involvement in remyelination. J. Neuroinflammation 2021, 18, 43. [CrossRef] [PubMed]

223. Hemphill, J.C., 3rd; Greenberg, S.M.; Anderson, C.S.; Becker, K.; Bendok, B.R.; Cushman, M.; Fung, G.L.; Goldstein, J.N.; Macdonald, R.L.; Mitchell, P.H.; et al. Guidelines for the Management of Spontaneous Intracerebral Hemorrhage: A Guideline for Healthcare Professionals from the American Heart Association/American Stroke Association. Stroke 2015, 46, 2032-2060. [CrossRef]

224. Shoamanesh Co-Chair, A.; Patrice Lindsay, M.; Castellucci, L.A.; Cayley, A.; Crowther, M.; de Wit, K.; English, S.W.; Hoosein, S.; Huynh, T.; Kelly, M.; et al. Canadian stroke best practice recommendations: Management of Spontaneous Intracerebral Hemorrhage, 7th Edition Update 2020. Int. J. Stroke 2021, 16, 321-341. [CrossRef] [PubMed]

225. Yen, H.C.; Jeng, J.S.; Chen, W.S.; Pan, G.S.; Chuang Pt Bs, W.Y.; Lee, Y.Y.; Teng, T. Early Mobilization of Mild-Moderate Intracerebral Hemorrhage Patients in a Stroke Center: A Randomized Controlled Trial. Neurorehabil. Neural. Repair. 2020, 34, 72-81. [CrossRef] 
226. Bai, Y.; Hu, Y.; Wu, Y.; Zhu, Y.; He, Q.; Jiang, C.; Sun, L.; Fan, W. A prospective, randomized, single-blinded trial on the effect of early rehabilitation on daily activities and motor function of patients with hemorrhagic stroke. J. Clin. Neurosci. 2012, 19, 1376-1379. [CrossRef]

227. Liu, N.; Cadilhac, D.A.; Andrew, N.E.; Zeng, L.; Li, Z.; Li, J.; Li, Y.; Yu, X.; Mi, B.; Li, Z.; et al. Randomized controlled trial of early rehabilitation after intracerebral hemorrhage stroke: Difference in outcomes within 6 months of stroke. Stroke 2014, 45, 3502-3507. [CrossRef]

228. Sreekrishnan, A.; Leasure, A.C.; Shi, F.D.; Hwang, D.Y.; Schindler, J.L.; Petersen, N.H.; Gilmore, E.J.; Kamel, H.; Sansing, L.H.; Greer, D.M.; et al. Functional Improvement Among Intracerebral Hemorrhage (ICH) Survivors up to 12 Months Post-injury. Neurocrit. Care 2017, 27, 326-333. [CrossRef]

229. Mestriner, R.G.; Pagnussat, A.S.; Boisserand, L.S.; Valentim, L.; Netto, C.A. Skilled reaching training promotes astroglial changes and facilitated sensorimotor recovery after collagenase-induced intracerebral hemorrhage. Exp. Neurol. 2011, $227,53-61$. [CrossRef]

230. Santos, M.V.; Pagnussat, A.S.; Mestriner, R.G.; Netto, C.A. Motor Skill Training Promotes Sensorimotor Recovery and Increases Microtubule-Associated Protein-2 (MAP-2) Immunoreactivity in the Motor Cortex after Intracerebral Hemorrhage in the Rat. ISRN Neurol. 2013, 2013, 159184. [CrossRef]

231. MacLellan, C.L.; Plummer, N.; Silasi, G.; Auriat, A.M.; Colbourne, F. Rehabilitation promotes recovery after whole blood-induced intracerebral hemorrhage in rats. Neurorehabil. Neural. Repair. 2011, 25, 477-483. [CrossRef] [PubMed]

232. Auriat, A.M.; Colbourne, F. Delayed rehabilitation lessens brain injury and improves recovery after intracerebral hemorrhage in rats. Brain Res. 2009, 1251, 262-268. [CrossRef]

233. Auriat, A.M.; Wowk, S.; Colbourne, F. Rehabilitation after intracerebral hemorrhage in rats improves recovery with enhanced dendritic complexity but no effect on cell proliferation. Behav. Brain Res. 2010, 214, 42-47. [CrossRef]

234. Caliaperumal, J.; Colbourne, F. Rehabilitation improves behavioral recovery and lessens cell death without affecting iron, ferritin, transferrin, or inflammation after intracerebral hemorrhage in rats. Neurorehabil. Neural. Repair. 2014, 28, 395-404. [CrossRef] [PubMed]

235. Tamakoshi, K.; Ishida, A.; Takamatsu, Y.; Hamakawa, M.; Nakashima, H.; Shimada, H.; Ishida, K. Motor skills training promotes motor functional recovery and induces synaptogenesis in the motor cortex and striatum after intracerebral hemorrhage in rats. Behav. Brain Res. 2014, 260, 34-43. [CrossRef] [PubMed]

236. Takamatsu, Y.; Ishida, A.; Hamakawa, M.; Tamakoshi, K.; Jung, C.G.; Ishida, K. Treadmill running improves motor function and alters dendritic morphology in the striatum after collagenase-induced intracerebral hemorrhage in rats. Brain Res. 2010, 1355, 165-173. [CrossRef] [PubMed]

237. Hays, S.A.; Khodaparast, N.; Hulsey, D.R.; Ruiz, A.; Sloan, A.M.; Rennaker, R.L., 2nd; Kilgard, M.P. Vagus nerve stimulation during rehabilitative training improves functional recovery after intracerebral hemorrhage. Stroke 2014, 45, 3097-3100. [CrossRef]

238. Lo, A.C.; Guarino, P.D.; Richards, L.G.; Haselkorn, J.K.; Wittenberg, G.F.; Federman, D.G.; Ringer, R.J.; Wagner, T.H.; Krebs, H.I.; Volpe, B.T.; et al. Robot-assisted therapy for long-term upper-limb impairment after stroke. N. Engl. J. Med. 2010, 362, 1772-1783. [CrossRef]

239. Gross, B.A.; Jankowitz, B.T.; Friedlander, R.M. Cerebral Intraparenchymal Hemorrhage: A Review. JAMA 2019, 321, 1295-1303. [CrossRef]

240. Tatlisumak, T.; Cucchiara, B.; Kuroda, S.; Kasner, S.E.; Putaala, J. Nontraumatic intracerebral haemorrhage in young adults. Nat. Rev. Neurol. 2018, 14, 237-250. [CrossRef]

241. Katan, M.; Luft, A. Global Burden of Stroke. Semin. Neurol. 2018, 38, 208-211. [CrossRef] [PubMed] 